\title{
Effect of Broussonetia papyrifera silage on the serum indicators, hindgut parameters and fecal bacterial community of Holstein heifers
}

Hanchen Tian, Yiye Chen, Ni Zhu, Yongqing Guo, Ming Deng, Guangbin Liu, Yaokun Li, Dewu Liu and Baoli Sun*

\begin{abstract}
This study investigated the effects of substitution of whole corn silage (WCS) with Broussonetia papyrifera silage (BPS) in different ratios on the serum indicators, hindgut fermentation parameters $(\mathrm{pH}$, ammoniacal nitrogen, and volatile fatty acids), and fecal bacterial community of Holstein heifers. Sixteen heifers (8-month-old, $220 \pm 30 \mathrm{~kg}$ ) were randomly divided into four treatments according to different BPS substitution ratios of feed basis $(0 \%, 25 \%, 50 \%$, and 75\%). The experiment consisted of a 7-day preliminary feeding period and a 30-day experimental period. On the last day of the trial, the blood samples were collected from caudal vein, and the feces samples were collected from rectum. With the increasing of BPS content, the concentration of malondialdehyde (MDA) and interleukin-1 $\beta$ (IL-1 $\beta$ ) in serum decreased $(P<0.05)$, and the immunoglobulin $A(\lg A)$ and IL-4 content of serum increased $(P<0.05)$; and the hindgut $\mathrm{pH}$ value increased $(P<0.05)$. 16S rRNA sequencing found that the dominant phyla were Firmicutes, Bacteroidetes, and Verrucomicrobia; and the dominant genera were Ruminococcaceae_UCG-005, Ruminococcaceae_UCG010, and Rikenellaceae_RC9_gut_group. Linear Discriminant Analysis Effect Size (LEfSe) analysis found 12 differential operational taxonomic units (OTUs) which have strong correlation with some serum and hindgut indicators, and have the potential to be used as biomarkers. Phylogenetic Investigation of Communities by Reconstruction of Unobserved States (PICRUSt) found that BPS have impacts on the pathways, such as carbohydrate transport and metabolism, and promotes amino acid transport and metabolism. To sum up, inclusion of BPS in heifer diets can affect serum anti-oxidant and immune indicators, fecal parameters, composition and function of fecal microorganisms in Holstein heifers.
\end{abstract}

Keywords: Broussonetia papyrifera silage, Holstein heifers, Serum indicators, Hindgut fermentantion, Fecal bacterial community

\section{Introduction}

With the increase of population and the decrease of arable land per capita, conventional feed such as forage and grain can no longer meet the need of animal husbandry (Dong et al. 2019; Zhai et al. 2020). In order to meet the demand of intensive animal production, it will

*Correspondence: baolisun@scau.edu.cn

College of Animal Science, South China Agricultural University,

510642 Guangzhou, China be necessary to make novel and unconventional feed resources available (Araújo et al. 2019). Unconventional feed materials are those that are not commonly used in formulations or have little research on their nutritional properties and feeding value, but have high yield and wide distribution and varieties. Currently, unconventional feed like Chinese jujube meal, pomegranate residue, orange leaves, olive leaves have been reported (Xie et al. 2018; Fernández et al. 2019; Hukerdi et al. 2019; Khorsandi et al. 2019). The above studies showed that 
those unconventional feed can promote the production performance of livestocks to some extent with no adverse effect.

Broussonetia papyrifera (Paper mulberry), a deciduous tree of Moraceae family, is widely distributed in China, Japan and other Asian countries (Yao et al. 2017). Many biologically active compounds contained in B. papyrifera, such as flavonoids, lignans, polysaccharides, and terpenoids might have antimicrobial, anti-inflammatory, and antioxidant properties and can reduce the growth of tumors (Mei et al. 2009; Sohn et al. 2010; Wang et al. 2010; Xu et al. 2010; Sun et al. 2012; Guo et al. 2013; Han et al. 2016). For this reason, B. papyrifera is already widely used in the pharmaceutical industry. Due to its high-quality fiber, B. papyrifera is also used as important raw material for the production of paper (Peng et al. 2019). B. papyrifera has advantages of rapid growth, strong adaptability and disease resistance, and high protein content (approximate 18-22\%, including both leaves and stems) (Peng et al. 2019), which makes it a potential candidate for new feed resourse.

Intestinal bacteria, which are diverse and abundant, play vital parts in maintaining the homeostasis of the digestive system and the function of the immune system (Liu et al. 2019). Intestinal bacteria have two main functions: converting nutrients into energy and resisting the invasion of pathogenic microorganisms (Guarner 2007). The stability of intestinal flora is directly related to animal physical condition, thus affecting production performance. In ruminant, intestinal flora is influenced by feed ingredients. Xie et al. (2020) fed Holstein heifers by substituting different proportions $(0 \%, 5 \%$, and $10 \%)$ of whole corn silage (WCS) with herbal tea residue, finding that the microbial composition of the three treatments was significantly different. Moreover, Sun et al. (2017) fed Holstein cows different percentages of ensiled Moringa oleifera and found a strong correlation between the presence of Akkermansia and Prevotella in total milk yield and milk protein, which indicates that some bacterial groups could be associated with enhanced milk production performance.

WCS is the most common forage used in ruminant production in China. However, due to some constraints (climate, soil type, etc.), the yield of WSC and other common forages in some regions in China could meet the requirement of local ruminant production. As a new feed material, B. papyrifera has been applied in aquaculture, pig, poultry, and ruminant production. Nevertheless, studies on the effects of feeding B. papyrifera silage to Holstein cows are still limited. In the present study, effects of substitution of WCS with different proportions of B. papyrifera silage (BPS) on the serum antioxidant and immune indicators; hindgut fermentation parameters including $\mathrm{pH}$ value, ammoniacal nitrogen $\left(\mathrm{NH}_{3}-\mathrm{N}\right)$, and volatile fatty acid (VFA); and fecal bacterial community of Holstein heifers were studied, providing a reference for the application of B. papyrifera in production. In depth, we analyzed the correlation between bacterial community and various serum and hindgut indicators, and predicted the function of bacterial community, in order to reveal the cause of differences caused by feed on the microbial level.

\section{Materials and methods}

All experimental procedures used in this study were approved by the Committee of Animal Experiments of South China Agricultural University (No. 201004152).

\section{Experimental materials}

$B$. papyrifera silage was purchased from a feed company (Heyuan, GD, China). Hybrid B. papyrifera was cut off when it reached a height of 1-1.5 m, and the trunk and branches were removed by a straw chopper, leaving the front $20-30 \mathrm{~cm}$ thin branches and leaves, and cutting them into $1 \mathrm{~cm}$ per segment. After air drying moderately, the mince, including leaves and twigs, was made into silage via stretch-film-wrapped silage technology $(30.00 \pm 5.00 \mathrm{~kg} / \mathrm{bale})$. Then the packaged silages were preserved in a dry and room-temperature indoor environment for 60 days.

\section{Experimental animals}

This experiment was carried out in a commercial dairy farm (Yangjiang, GD, China) and adopted a completely randomized block, including a 7-day preliminary feeding period and a 30-day experimental period. Sixteen healthy 8-month-old Holstein heifers $(220 \pm 30 \mathrm{~kg})$ were randomly assigned to four treatments. In the four groups, the substitution ratios (feed basis) of BPS for WCS in diets was 0\% (T0), 25\% (T25), 50\% (T50), and $75 \%$ (T75), respectively. The total mixed ration (TMR) were formulated based on Chinese feeding standards (China Standard NY/T34, 2004). The nutrient composition of WCS, BPS, and TMR were analyzed. Thereinto, dry matter (DM), crude protein $(\mathrm{CP})$, ether extract (EE) were measured according to Association of Official Analytical Chemists (AOAC 2002); neutral detergent fiber (NDF), acid detergent fiber (ADF), and hemicellulose (HC) were tested based on Van Soest et al. (1991); calcium (Ca) was measured via EDTA complexometric titration method; phosphorus (P) was determined via vanadium molybdate yellow colorimetric method. The nutrient content of WCS and BPS were shown in Table 1. The ingredient and nutrient content of TMRs were shown in Table 2. Heifers were fed twice per day (10:00 and 16:00), and had ad libitum access to feed and water 
Table 1 Chemical composition of WCS and BPS

\begin{tabular}{lrr}
\hline Item & WCS & BPS \\
\hline $\mathrm{DM}$ & 30.50 & 30.86 \\
$\mathrm{CP}(\% / \mathrm{DM})$ & 10.70 & 14.34 \\
$\mathrm{EE}(\% / \mathrm{DM})$ & 3.30 & 2.33 \\
$\mathrm{NDF}(\% / D M)$ & 60.10 & 49.23 \\
ADF (\%/DM) & 38.90 & 31.21 \\
Ash (\%/DM) & 11.37 & 11.52 \\
\hline
\end{tabular}

WCS, whole corn silage; BPS, Broussonetia papyrifera silage; DM, dry matter; $C P$, crude protein; $E E$, ether extract; NDF, neutral detergent fiber; $A D F$, acid detergent fiber

Table 2 Ingredients and chemical composition of the diets

\begin{tabular}{lrrrr}
\hline Item $^{\mathbf{a}}$ & \multicolumn{3}{c}{ Diets treatment } \\
\cline { 2 - 5 } & \multicolumn{1}{c}{ T0 } & \multicolumn{1}{c}{ T25 } & \multicolumn{1}{c}{ T50 } & \multicolumn{1}{c}{ T75 } \\
\hline Ingredient (as fed-basis \%) & & & & \\
Hay & 13.07 & 13.14 & 13.22 & 13.29 \\
Soybean meal & 3.40 & 3.07 & 2.91 & 2.66 \\
Salt & 0.17 & 0.18 & 0.18 & 0.18 \\
Mineral premix & 0.09 & 0.09 & 0.09 & 0.09 \\
Indian meal & 2.61 & 2.41 & 1.98 & 1.77 \\
DDGS & 2.26 & 2.28 & 2.29 & 2.30 \\
Brewer's grains & 8.71 & 8.76 & 8.81 & 8.86 \\
BPS & 0.00 & 17.52 & 35.26 & 53.14 \\
WCS & 69.69 & 52.55 & 35.26 & 17.71 \\
Nutrient content & & & & \\
CP (\%DM) & 13.44 & 14.92 & 13.30 & 15.44 \\
EE (\%DM) & 2.10 & 1.89 & 1.91 & 1.94 \\
NDF (\%DM) & 51.48 & 50.46 & 50.14 & 50.34 \\
ADF (\%DM) & 30.02 & 31.32 & 30.20 & 30.78 \\
HC (\%DM) & 21.46 & 19.14 & 19.94 & 19.56 \\
Ca (\%DM) & 0.78 & 0.79 & 0.80 & 0.78 \\
P (\%DM) & 0.45 & 0.43 & 0.43 & 0.44 \\
RUP (\%CP) & 42.27 & 42.65 & 43.22 & 43.59 \\
ME (mcal/kg DM) & 1.86 & 1.87 & 1.88 & 1.89 \\
\hline & & & \\
\hline
\end{tabular}

a DDGS, distillers dried grains with solubles; BPS, Broussonetia papyrifera silage; WCS, whole corn silage; DM, dry matter; $C$, crude protein; $E$, ether extract; NDF, neutral detergent fiber; $A D F$, acid detergent fiber; $H C$, hemicellulose; RUP, rumen undegradable protein; ME, metabolizable energy

b T0, BPS replaces $0 \%$ of WCS; T25, BPS replaces $25 \%$ of WCS; T50, BPS replaces $50 \%$ of WCS; T75, BPS replaces $75 \%$ of WCS. BPS, Broussonetia papyrifera silage; WCS, whole corn silage

c Mineral premix provided the following per kg of concentrate, vitamin $\mathrm{A}$, 120-180 KIU; vitamin D3, 40-60 KIU; vitamin E, $\geq 1,102 \mathrm{mg} ; \mathrm{Cu}, 459-613 \mathrm{mg} ; \mathrm{Mn}$, 918-1,225 mg; Zn, 1,840-2,455 mg; Se, 12-18 mg; l, 22.5-30 mg; Co, 5.4-7.34 mg

throughout the experimental period. The heifers were kept in a wide-open free-stall barn with natural ventilation and the excrement was cleaned artificially every day. The cowshed took natural light during the day and artificial light at night, in order to ensure all-day illumination.
The blood and feces samples were collected at $4 \mathrm{~h}$ after morning feeding on the last day of experimental period. The blood (approximately $20 \mathrm{~mL}$ ) was collected from caudal vein; after centrifugation (4000 r/min, $15 \mathrm{~min}$ ), the upper serum was separated and stored at $-20{ }^{\circ} \mathrm{C}$. The feces samples were collected from rectum, approximately $2 \mathrm{~g}$ of each samples were stored at $-80^{\circ} \mathrm{C}$ for the determination of microbial flora, another $10 \mathrm{~g}$ was taken and added into $20 \mathrm{~mL}$ of double steamed water for the determination of fecal parameters, including $\mathrm{pH}, \mathrm{NH}_{3}-\mathrm{N}$, and VFAs.

\section{Serum indicators determination}

Serum antioxidant indicators, including malondialdehyde (MDA), superoxide dismutase (SOD), glutathione peroxidase (GSH-Px), catalase (CAT), and total antioxidant capacity (T-AOC), were tested via a commercial kit (Nanjing Jiancheng Bio-Engineering Co. Ltd., Nanjing, China) (Peng et al. 2020). Serum immune indicators, including immunoglobulin A (IgA), interleukin $1 \beta$ (IL-1 $\beta$ ), IL-2, IL-4, IL-6, IL-10, and IL-17, were tested via enzyme-linked immunosorbent assay (ELISA) kit (Jiangsu Jingmei Biotechnology Co. Ltd., Yancheng, China) (Dong et al. 2019). The detailed operating steps of kits were showed in manufacture's protocols in detail.

\section{Hindgut fermentation parameters determination}

Approximately $10 \mathrm{~g}$ of each fresh feces sample was mixed with $20 \mathrm{~mL}$ distilled water, and then shaked up and centrifuged $(5400 \mathrm{rpm} \times 10 \mathrm{~min}$ ). The supernatant was collected to test $\mathrm{pH}$-value and the content of $\mathrm{NH}_{3}-\mathrm{N}$ and VFAs, including acetic acid (AA), propionic acid (PA), isobutyric acid (IBA), butyric acid (BA), isovaleric acid (IVA), and valeric acid (VA).

The determination of $\mathrm{NH}_{3}-\mathrm{N}$ content were according to the method of Broderick and Kang (1980). Briefly, a spectrophotometer (UV-2600, Unico, Shanghai) was used for colorimetry, and the standard curve was obtained according to OD value of standard ammonia solution. The prepared phenol reagent and sodium hypochlorite reagent were successively added to the supernatant mentioned above, after water bath, OD value of the solution was calculated at the wavelength of $630 \mathrm{~nm}$.

The determination of volatile fatty acids (VFA) was based on the method described by Erwin et al. (1961), and the column selection was adjusted and some chromatographic operating conditions were optimized. The chromatographic column was HP-INNOWax capillary column and set to constant flow mode, flow: $2.0 \mathrm{~mL} /$ min, mean linear velocity: $38 \mathrm{~cm} / \mathrm{s}$. The parameters of gas chromatograph were set as follows: carrier gas, $\mathrm{N}_{2}$; injection volume, $0.6 \mu \mathrm{L}$; injection temperature, $220^{\circ} \mathrm{C}$; split ratio, 40:1. In this research, 2-ethyl BA (2-EB) was 
selected as the internal standard. Based on the established integral parameter and correction curve, the content of each component of the unknown sample was obtained by internal standard calculation method.

\section{Bacterial community analysis}

The total DNA of bacterial community was extracted via E.Z.N.A. ${ }^{\circledR}$ DNA Kit (Omega Biotek, Norcross, GA, USA) according to the specification. The ABI GeneAmp ${ }^{\circledR} 9700$ PCR Amplifier (ABI, Carlsbad, CA, USA) was adopted to amplify the $16 \mathrm{~S}$ rRNA V3-V4 regions. The primers were designed as follows: forward primer, 338F (ACT CCTACGGGAGGCAGCAG); and reverse primer, 806R (GGACTACHVGGGTWTCTAAT) (He et al. 2019). PCR system was as follows: $5 \times$ FastPfu buffer, $4 \mu \mathrm{L}$; $2.5 \mathrm{mM}$ dNTPs, $2 \mu \mathrm{L}$; forward primer $(5 \mu \mathrm{M}), 0.8 \mu \mathrm{L}$; reverse primer $(5 \mu \mathrm{M}), 0.8 \mu \mathrm{L}$; FastPfu polymerase, 0.4 $\mu \mathrm{L}$; bovine serum albumin (BSA), $0.2 \mu \mathrm{L}$; template DNA, $10 \mathrm{ng}$; $\mathrm{ddH}_{2} \mathrm{O}$, fill to $20 \mu \mathrm{L}$. The reaction was performed under the following condition: $95{ }^{\circ} \mathrm{C}$ for $3 \mathrm{~min} ; 95^{\circ} \mathrm{C}$ for $30 \mathrm{~s}, 55{ }^{\circ} \mathrm{C}$ for $30 \mathrm{~s}, 72{ }^{\circ} \mathrm{C}$ for $45 \mathrm{~s}$ for 27 cycles; $72{ }^{\circ} \mathrm{C}$ for $10 \mathrm{~min}$. After purification, detection, and quantification, the PCR products were sequenced via Illumina Miseq platform (Majorbio Bio-Pharm Technology Co. Ltd., Shanghai, China). After sequencing, the raw data was analyzed according to Sun et al. (2017).

\section{Statistical analysis}

Serum and fecal parameters were analyzed using SAS 9.4 software (SAS Institute Inc., Cary, NC, USA). Briefly, INFLUENCE statement was used for outlier elimination; GLM procedure was invoked for data processing; LSMEANS statement was adopted to calculate least squares mean; Tukey method was used for multicomparison. The model used for data processing is: $\mathrm{Y}_{\mathrm{ij}}=\mu+\mathrm{T}_{\mathrm{i}}+\varepsilon_{\mathrm{ij}}$, thereinto, $\mathrm{Y}_{\mathrm{ij}}$ is the dependent variable value of the test heifers in different treatments; $\mu$ is the overall mean; $T_{i}$ is the diets treatment effects; $\varepsilon_{i j}$ is the random error. Orthogonal polynomial contrasts (linear, quadratic, and cubic) were used to analyze the effects of the different BPS inclusion levels on the serum and fecal parameters. The experimental data were presented in tables with mean value and standard error of mean (SEM), $P<0.05$ indicated significant differences.

Linear Discriminant Analysis (LDA) Effect Size (LEfSe) analysis was performed via an online tool (http://hutte nhower.sph.harvard.edu/galaxy/2 in order to obtain differential operational taxonomic units (OTU). Principal component analysis (PCA) and Adonis analysis were performed via vegan package in $\mathrm{R}$ 4.0.3 software. The correlation analyses between differential OTU and various indicators were carried out via WGCNA package in $\mathrm{R}$ 4.0.3 software (Sun et al. 2017); and the results showed
P-Value and correlation coefficient $\left(\mathrm{C}_{\mathrm{XY}}\right)$. Clusters of Orthologous Groups (COG) functional annotation and Kyoto Encyclopedia of Genes and Genomes (KEGG) sample abundance statistics were computed via Phylogenetic Investigation of Communities by Reconstruction of Unobserved States (PICRUSt) on Majorbio (Shanghai, China) online platform (http://www.i-sanger.com).

\section{Results}

Serum indicators and hindgut fermentation parameters

The MDA content of T50 declined linearly $(P<0.05)$ compared to T0 (Table 3), no significant differences were found between T25 and T75. Other antioxidant indicators had no significant differences in the four treatments. For serum immune indicators (Table 2), compared with T0, the IgA content of T25, T50, and T75, the IL- 4 content of T75 increased (linear, $P<0.05$ ); the IL- $1 \beta$ content of T50 and T75 decreased (linear, $P<0.05$ ). The IL-10 content of T75 was significantly lower than that in T25 $(P<0.05)$. For hindgut fermentation parameters (Table 4$)$, the $\mathrm{pH}$ value of T25 was higher than that in T0 $(P<0.05)$; the $\mathrm{NH}_{3}-\mathrm{N}$ content of T50 and T75 increased compared with T25 $(P<0.05)$, there was no difference between T0 and the other three group treated with BPS. Other indicators did not differ significantly between the four treatments.

\section{S rRNA gene sequencing and analysis}

Miseq high-throughput sequencing was performed on the V3-V4 region of 16S rRNA, and a total of 424,032 effective sequences were obtained, 26,502 for each sample. According to high-throughput sequencing results, cluster analysis of OTUs was conducted, and a total of 15 phyla, 26 classes, 39 orders, 67 families, 185 genera, 341 species, and 1356 OTUs were obtained. The Venn diagram of this study was shown in Fig. 1. As shown in the figure, the number of OTU that all the four treatments possess was 1186 , and it accounted for $87.46 \%$ of the total amount.

The rarefaction curve is commonly used to reflect the sequencing depth and coverage of test samples. Figure 2 shows that the rarefaction curve of 16 samples sequenced in this test did not enter the plateau phase when the number of sequencing reads reached 25,000, indicating that the sequencing data volume cannot absolutely represent all OTUs in the bacterial community of feces, and it is still possible to find new OTUs by increasing the sequencing data volume. However, the growth rate of rarefaction curve has slowed, suggesting a sufficient level of species richness. According to the coverage curve in Fig. 3, when the number of sequencing reads reached 10,000 , the coverage reached $97 \%$, and when the number of sequencing reads continued to grow to 25,000 , 
Table 3 Effects of BPS on the serum indicators of Holstein heifers $(n=4)$

\begin{tabular}{|c|c|c|c|c|c|c|c|c|}
\hline \multirow[t]{2}{*}{ Item $^{1}$} & \multicolumn{4}{|c|}{ Diets treatment ${ }^{2}$} & \multirow[t]{2}{*}{$\mathrm{SEM}^{3}$} & \multicolumn{3}{|c|}{ P-value } \\
\hline & TO & T25 & T50 & T75 & & Linear & Quadratic & Cubic \\
\hline \multicolumn{9}{|c|}{ Serum anti-oxidant indicators } \\
\hline $\mathrm{MDA}(\mathrm{mmol} / \mathrm{L})$ & $2.61^{\mathrm{a}}$ & $2.24^{\mathrm{ab}}$ & $1.79^{b}$ & $2.34^{\mathrm{ab}}$ & 0.20 & 0.018 & 0.675 & 0.242 \\
\hline $\mathrm{SOD}(\mathrm{U} / \mathrm{mL})$ & 88.90 & 88.93 & 87.48 & 85.46 & 2.68 & 0.332 & 0.708 & 0.942 \\
\hline $\mathrm{GSH}-\mathrm{Px}(\mathrm{U} / \mathrm{mL})$ & 58.45 & 50.31 & 44.50 & 43.63 & 7.40 & 0.134 & 0.631 & 0.941 \\
\hline CAT $(\mathrm{U} / \mathrm{mL})$ & 0.47 & 0.50 & 0.37 & 0.42 & 0.05 & 0.286 & 0.827 & 0.161 \\
\hline $\mathrm{T}-\mathrm{AOC}(\mathrm{mmol} / \mathrm{L})$ & 0.46 & 0.41 & 0.43 & 0.41 & 0.02 & 0.128 & 0.513 & 0.221 \\
\hline \multicolumn{9}{|c|}{ Serum immune indicators } \\
\hline $\lg A(g / L)$ & $0.11^{b}$ & $0.13^{\mathrm{a}}$ & $0.14^{\mathrm{a}}$ & $0.14^{\mathrm{a}}$ & 0.01 & 0.019 & 0.224 & 0.774 \\
\hline$\| L-1 \beta(n g / L)$ & $46.86^{\mathrm{a}}$ & $45.61^{\mathrm{a}}$ & $38.77^{\mathrm{b}}$ & $40.08^{b}$ & 2.20 & 0.011 & 0.572 & 0.210 \\
\hline IL-2 (ng/L) & 292.84 & 290.91 & 281.16 & 252.76 & 15.47 & 0.054 & 0.974 & 0.718 \\
\hline IL-4 (ng/L) & $77.99^{b}$ & $83.62^{b}$ & $93.19^{\mathrm{ab}}$ & $106.34^{\mathrm{a}}$ & 5.21 & 0.001 & 0.482 & 0.988 \\
\hline IL-6 (ng/L) & 11.39 & 10.36 & 10.46 & 9.88 & 0.87 & 0.263 & 0.796 & 0.657 \\
\hline IL-10 (ng/L) & $43.93^{\mathrm{ab}}$ & $48.03^{\mathrm{a}}$ & $43.90^{\mathrm{ab}}$ & $41.44^{b}$ & 1.90 & 0.122 & 0.483 & 0.558 \\
\hline IL-17 (ng/L) & 56.05 & 51.56 & 45.33 & 52.55 & 3.29 & 0.254 & 0.097 & 0.341 \\
\hline
\end{tabular}

1 MDA, malondialdehyde; SOD, superoxide dismutase; GSH-Px, glutathione peroxidase; CAT, catalase; T-AOC, total antioxidant capacity; Ig, immunoglobulin A; IL, interleukin

2 T0, BPS replaces $0 \%$ of WCS; T25, BPS replaces $25 \%$ of WCS; T50, BPS replaces $50 \%$ of WCS; T75, BPS replaces $75 \%$ of WCS. BPS, Broussonetia papyrifera silage; WCS, whole corn silage. Different letters mean significant difference

3 SEM, standard error of mean

Table 4 Effects of BPS on the hindgut fermentation parameters of Holstein heifers $(n=4)$

\begin{tabular}{|c|c|c|c|c|c|c|c|c|}
\hline \multirow[t]{2}{*}{ Item $^{1}$} & \multicolumn{4}{|c|}{ Diets treatment ${ }^{2}$} & \multirow[t]{2}{*}{ SEM $^{3}$} & \multicolumn{3}{|l|}{ P-value } \\
\hline & T0 & T25 & T50 & T75 & & Linear & Quadratic & Cubic \\
\hline $\mathrm{pH}$ & $6.79^{a}$ & $7.18^{b}$ & $7.02^{\mathrm{ab}}$ & $7.05^{b c}$ & 0.10 & 0.174 & 0.091 & 0.146 \\
\hline $\mathrm{AA}(\mathrm{mmol} / \mathrm{L})$ & 12.26 & 11.48 & 11.34 & 11.00 & 1.24 & 0.470 & 0.858 & 0.887 \\
\hline PA (mmol/L) & 2.51 & 2.17 & 2.28 & 2.17 & 0.26 & 0.432 & 0.655 & 0.584 \\
\hline IVA (mmol/L) & 0.34 & 0.35 & 0.39 & 0.37 & 0.03 & 0.304 & 0.566 & 0.481 \\
\hline BA (mmol/L) & 1.14 & 0.87 & 0.79 & 0.98 & 0.16 & 0.428 & 0.173 & 0.906 \\
\hline IVA (mmol/L) & 0.28 & 0.29 & 0.32 & 0.31 & 0.02 & 0.212 & 0.711 & 0.731 \\
\hline VA (mmol/L) & 0.20 & 0.18 & 0.18 & 0.21 & 0.03 & 0.830 & 0.286 & 0.948 \\
\hline $\mathrm{NH}_{3}-\mathrm{N}(\mathrm{mg} / \mathrm{dL})$ & $5.52^{a b c}$ & $4.47^{\mathrm{a}}$ & $5.40^{\mathrm{b}}$ & $5.98^{b c}$ & 0.45 & 0.250 & 0.093 & 0.291 \\
\hline
\end{tabular}

1 AA, acetic acid; PA, propionic acid; IBA, isobutyric acid; BA, butyric acid; IVA, isovaleric acid; VA, valeric acid; $\mathrm{NH}_{3}-\mathrm{N}$, ammoniacal nitrogen

2 T0, BPS replaces $0 \%$ of WCS; T25, BPS replaces $25 \%$ of WCS; T50, BPS replaces 50\% of WCS; T75, BPS replaces $75 \%$ of WCS. BPS, Broussonetia papyrifera silage; WCS, whole corn silage. Different letters mean significant difference

${ }^{3}$ SEM, standard error of mean

the coverage was close to $100 \%$.It shows that the depth and coverage of sequencing data are reasonable and the measured data can be used for subsequent analysis. The rank-abundance curve of fecal samples was shown in Fig. 4. It can be seen from the figure that the microbial diversity of the 4 treatments is similar.

For $\alpha$-diversity, Shannon index, Ace index, and Chao index were calculated and the results were shown in Table 5. As we can see from the table, there were no significant differences in the above three indexes, indicating
BPS had no remarkably effect on the diversity and abundance of fecal bacteria community. For $\beta$-diversity, the results of PCA and Adonis were shown as Fig. 5; Table 6. As we can see in Fig. 5, the separation between Treatment $\mathrm{T} 0$ and other treatments is obvious. Table 6 showed that there are significant changes between Treatments $\mathrm{T} 0$ and T75 $(P<0.05)$.

The composition of bacterial community on the phylum and genus levels were shown in Fig. 6. Firmicutes and Bacteroidetes were the two most dominant phyla, 

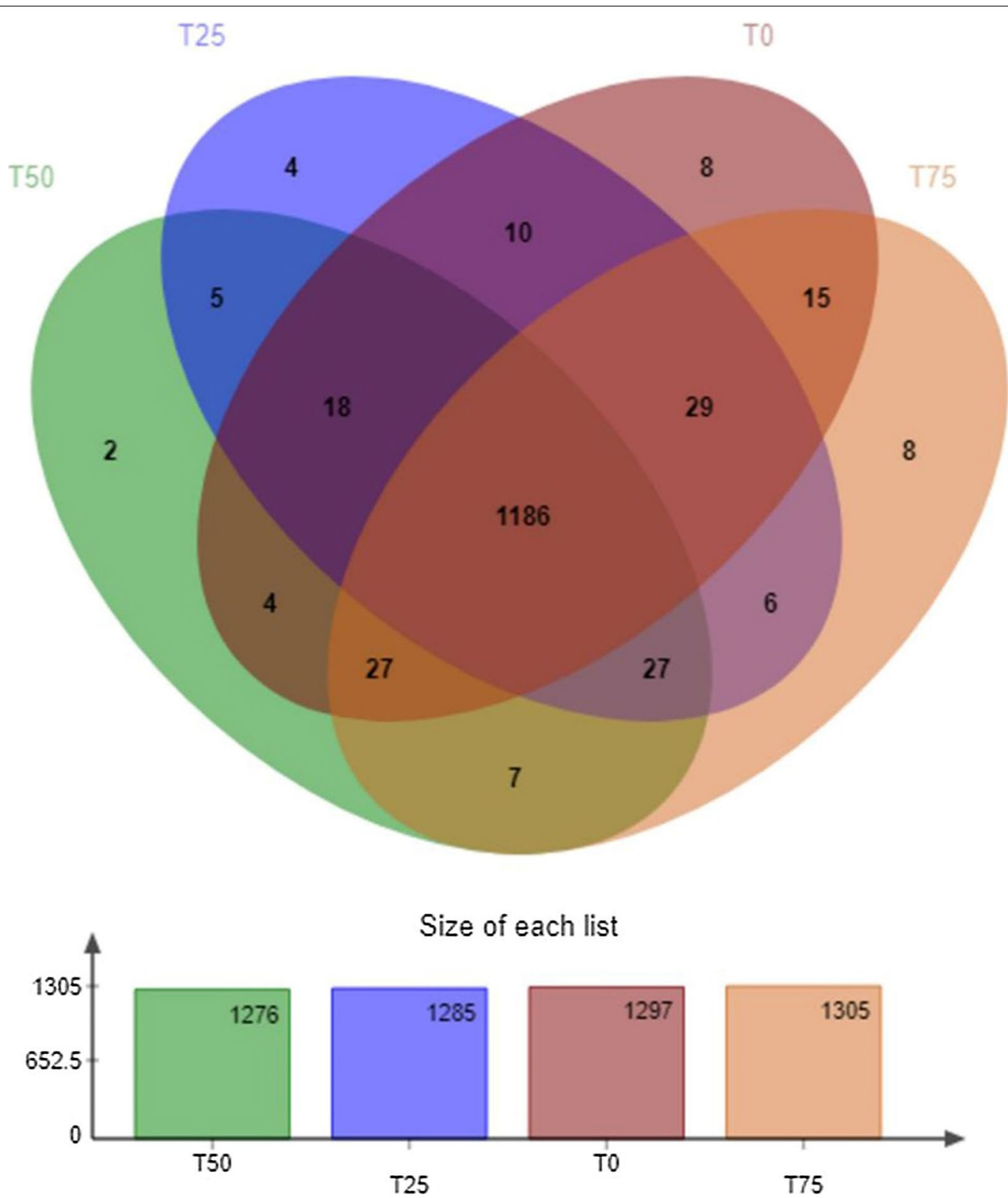

Fig. 1 Venn map of operational taxonomic units (OTU) in the four treatment. TO: BPS replaces 0\% of WCS; T25: BPS replaces 25\% of WCS; T50: BPS replaces 50\% of WCS; T75: BPS replaces 75\% of WCS. BPS, Broussonetia papyrifera silage; WCS, whole corn silage

accounting for more than $95 \%$ of the bacterial community. On the genus level, in different treatments, Ruminococcaceae_UCG-005, Ruminococcaceae_UCG-010, and Rikenellaceae_RC9_gut_group were always the first three dominant genera. With the increasing of BPS content, some phyla, including Firmicutes, Bacteroidetes, Tenericutes, Proteobacteria, and Verrucomicrobia, and some genera, including Paeniclostridium, Phocaeicola, and Norank_f_bacteroidales_BS11_gut_group, became more abundant; while other genera, such as
Ruminococcaceae_UCG-013, Ruminococcaceae_UCG010, and Ruminococcaceae_UCG-009 decrease.

\section{Correlation between differential OTUs and various indicators}

LDA score represented the influence of significantly different OTUs. The OTU, which its LDA score was greater than the set point, can be regarded as statistically significant biomarker. In the present study, the set point was 2, and 12 differential OTUs (Fig. 7), including 


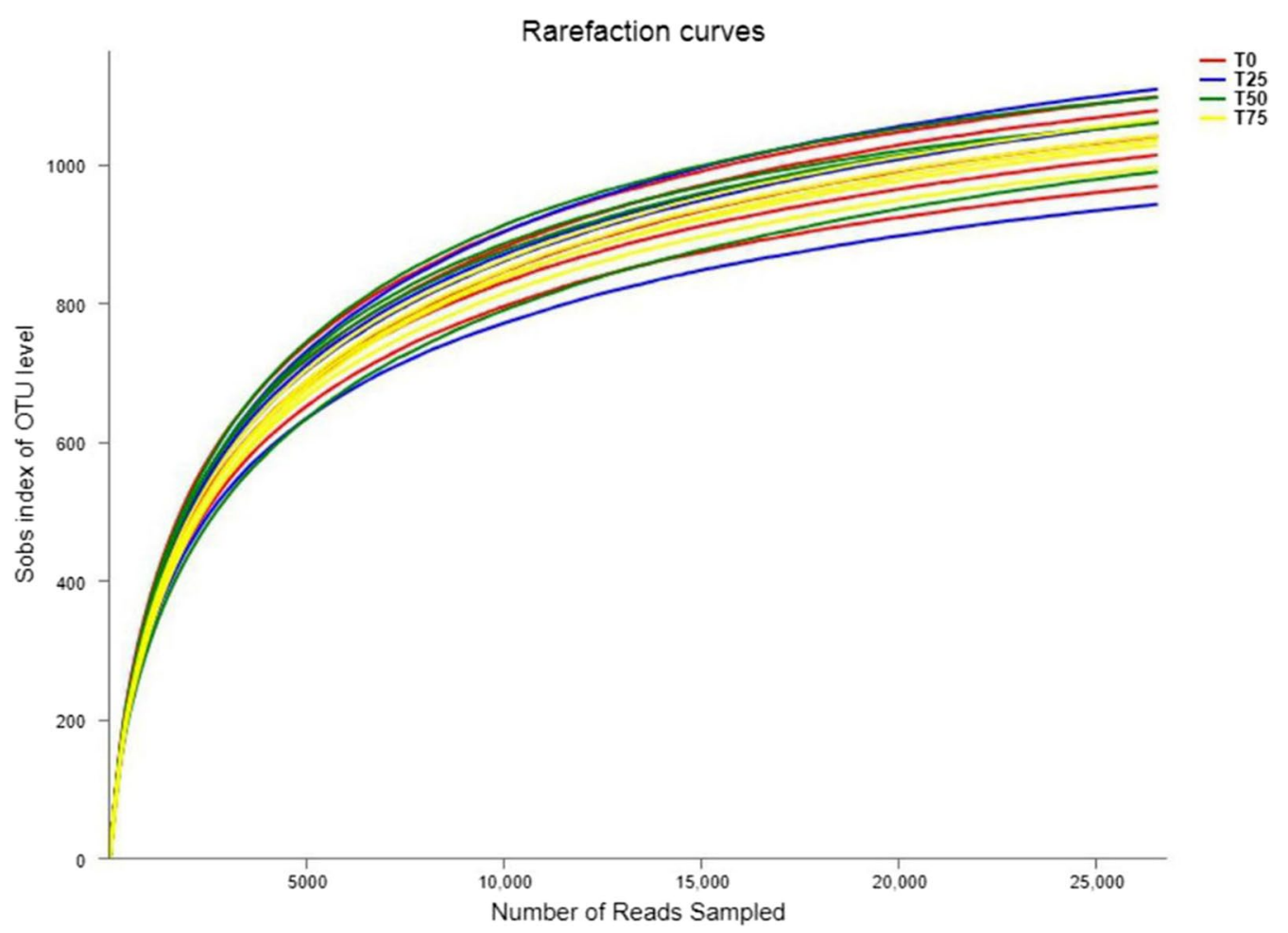

Fig. 2 Rarefaction curves of feces samples

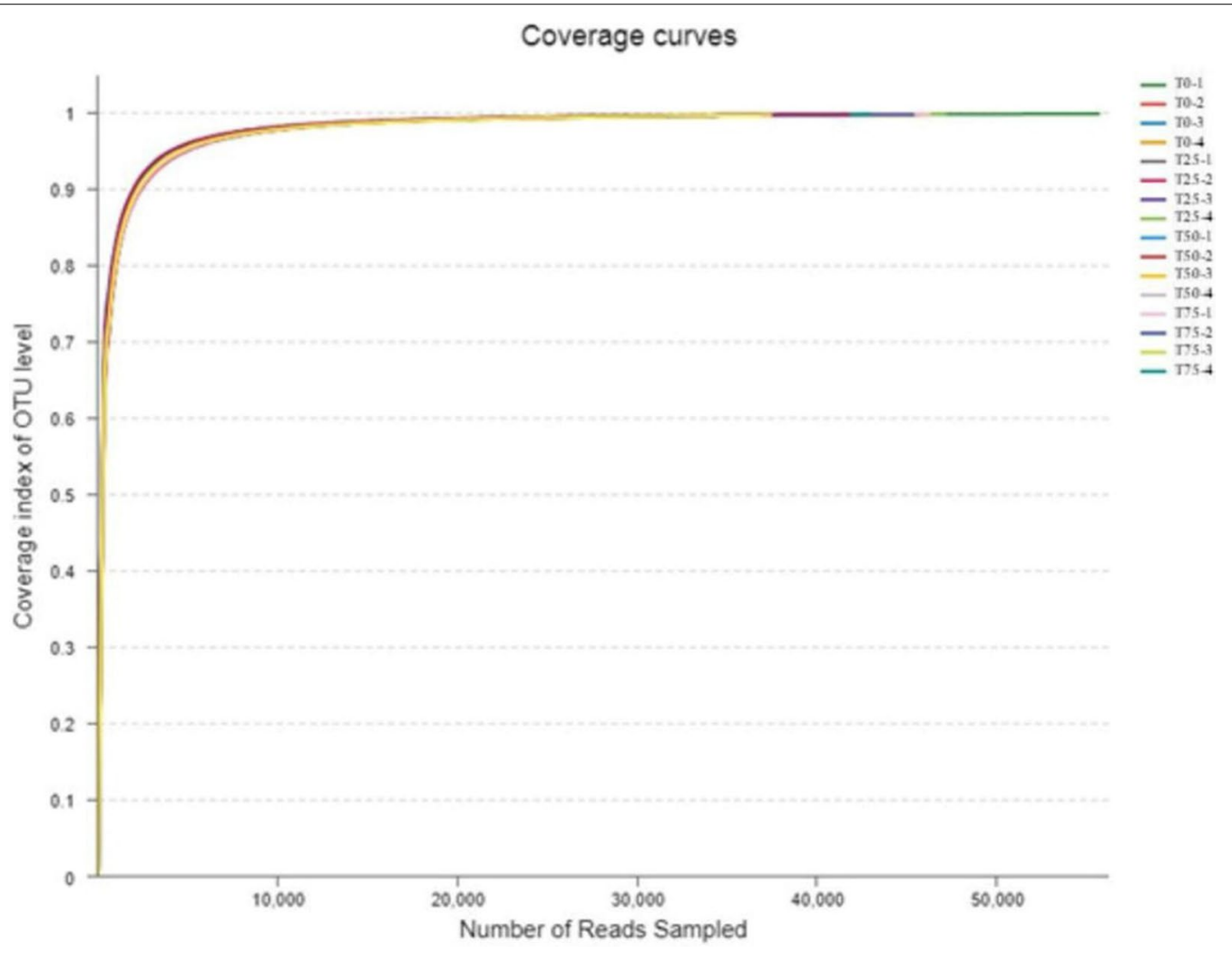

Fig. 3 Coverage curves of feces samples 


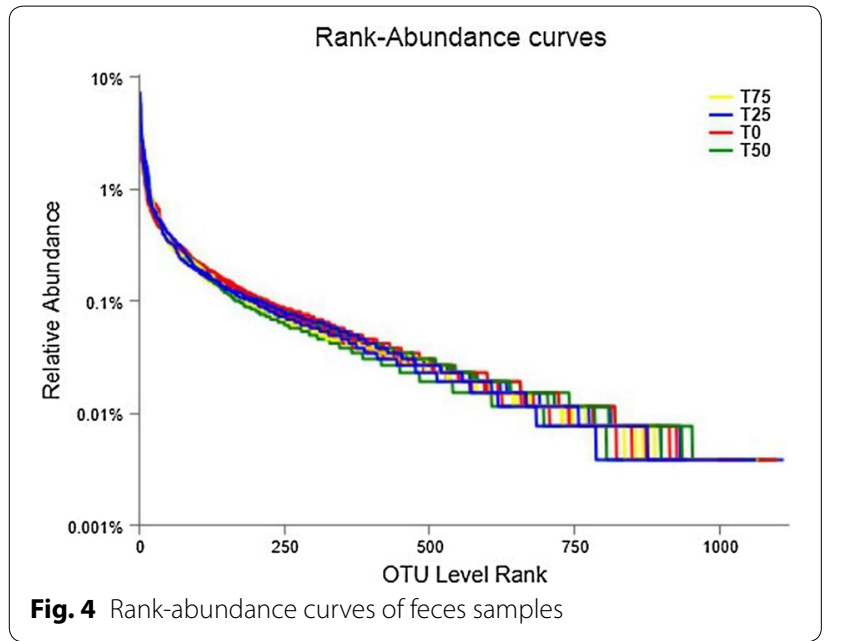

Peptostreptococcaceae (family), Paeniclostridium (genus), Thermoanaerobacteraceae (family), Unclassified_f_peptoccaceae (genus), Tyzzerella (genus), Gelria (genus), Thermoanaerobacterales (order), Roseburia (genus), Alphaproteobacteria (class), Ruminococcaceeae (family), Saccharofermentants (genus), and Coprococcus_3 (genus) were obtained. Figure $7 \mathrm{a}$ was the LDA score distribution histogram, the different colors represented their respective groups; and the length represented the LDA score, which is the degree of influence of the differential OTUs between the four treatments. Figure $7 \mathrm{~b}$ was the cladogram, the circle radiating from the inside to the outside represented the classification level from phylum to genus, and the diameter of the circle represented the relative abundance. The OTUs with no significant difference were uniformly colored yellow, and the differential OTUs followed the treatment.

In this study, differential OTUs were performed correlation analysis with serum antioxidant and immune indicators, and hindgut fermentation parameters (Fig. 8). For serum antioxidant indicators, Thermoanaerobacteraceae, Thermoanaerobacterales, and Gelria were positively correlated with $\mathrm{MDA}\left(\mathrm{C}_{\mathrm{XY}}=0.63\right.$, $\mathrm{P}=0.009 ; \mathrm{C}_{\mathrm{XY}}=0.63, \mathrm{P}=0.009 ; \mathrm{C}_{\mathrm{XY}}=0.63, \mathrm{P}=0.009$,

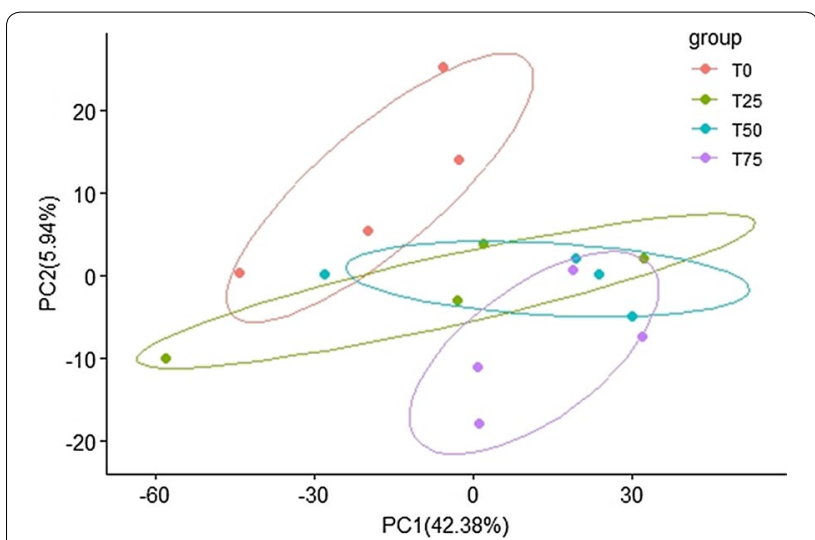

Fig. 5 Principal component analysis of the four treatment. TO: BPS replaces $0 \%$ of WCS; T25: BPS replaces 25\% of WCS; T50: BPS replaces $50 \%$ of WCS; T75: BPS replaces $75 \%$ of WCS. BPS, Broussonetia papyrifera silage; WCS, whole corn silage

Table 6 Adonis analysis of the four treatments

\begin{tabular}{lll}
\hline Items $^{\mathbf{a}}$ & $\mathbf{R}^{\mathbf{2}}$ & P value \\
\hline $\mathrm{T} 0 / \mathrm{T} 25$ & 0.1256 & 0.581 \\
$\mathrm{~T} 0 / \mathrm{T} 50$ & 0.2196 & 0.085 \\
$\mathrm{~T} 0 / \mathrm{T} 75$ & 0.2553 & 0.027 \\
$\mathrm{~T} 25 / \mathrm{T} 50$ & 0.1381 & 0.422 \\
$\mathrm{~T} 25 / \mathrm{T} 75$ & 0.1384 & 0.475 \\
$\mathrm{~T} 50 / \mathrm{T} 75$ & 0.1440 & 0.360 \\
\hline
\end{tabular}

a T0, BPS replaces $0 \%$ of WCS; T25, BPS replaces $25 \%$ of WCS; T50, BPS replaces $50 \%$ of WCS; T75, BPS replaces $75 \%$ of WCS. BPS, Broussonetia papyrifera silage; WCS, whole corn silage

respectively); Unclassified_f_peptoccaceae was negatively correlated with CAT $\left(\mathrm{C}_{\mathrm{XY}}=-0.53, \mathrm{P}=0.04\right)$. For serum immune indicators, Peptostreptococcaceae, Paeniclostridium, Thermoanaerobacteraceae, Gelria, and Thermoanaerobacterales had positive correlation with IL-4 $\left(C_{X Y}=0.58, P=0.02 ; C_{X Y}=0.56, P=0.03\right.$; $\mathrm{C}_{\mathrm{XY}}=0.62, \mathrm{P}=0.01 ; \mathrm{C}_{\mathrm{XY}}=0.62, \mathrm{P}=0.01 ; \mathrm{C}_{\mathrm{XY}}=0.62$, $\mathrm{P}=0.01$, respectively); Roseburia had positive correlation with IL-6 $\left(\mathrm{C}_{\mathrm{XY}}=0.58, \mathrm{P}=0.02\right)$; Saccharofermentants

Table 5 Effects of BPS on the a-diversity of hindgut bacterial community of Holstein heifers $(n=4)$

\begin{tabular}{|c|c|c|c|c|c|c|c|c|}
\hline \multirow[t]{2}{*}{ Item } & \multicolumn{4}{|c|}{ Diets treatment $^{a}$} & \multirow[t]{2}{*}{ SEM $^{\mathbf{b}}$} & \multicolumn{3}{|c|}{ P-value } \\
\hline & TO & $\mathrm{T} 25$ & T50 & T75 & & Linear & Quadratic & Cubic \\
\hline Shannon & 5.64 & 5.58 & 5.48 & 5.56 & 0.06 & 0.603 & 0.227 & 0.155 \\
\hline Ace & 1144.55 & 1145.67 & 1143.72 & 1153.51 & 24.18 & 0.794 & 0.860 & 0.978 \\
\hline Chao & 1150.60 & 1154.06 & 1147.21 & 1165.92 & 25.20 & 0.647 & 0.767 & 0.964 \\
\hline
\end{tabular}

a T0, BPS replaces $0 \%$ of WCS; T25, BPS replaces $25 \%$ of WCS; T50, BPS replaces $50 \%$ of WCS; T75, BPS replaces $75 \%$ of WCS. BPS, Broussonetia papyrifera silage; WCS, whole corn silage

b SEM, standard error of mean 

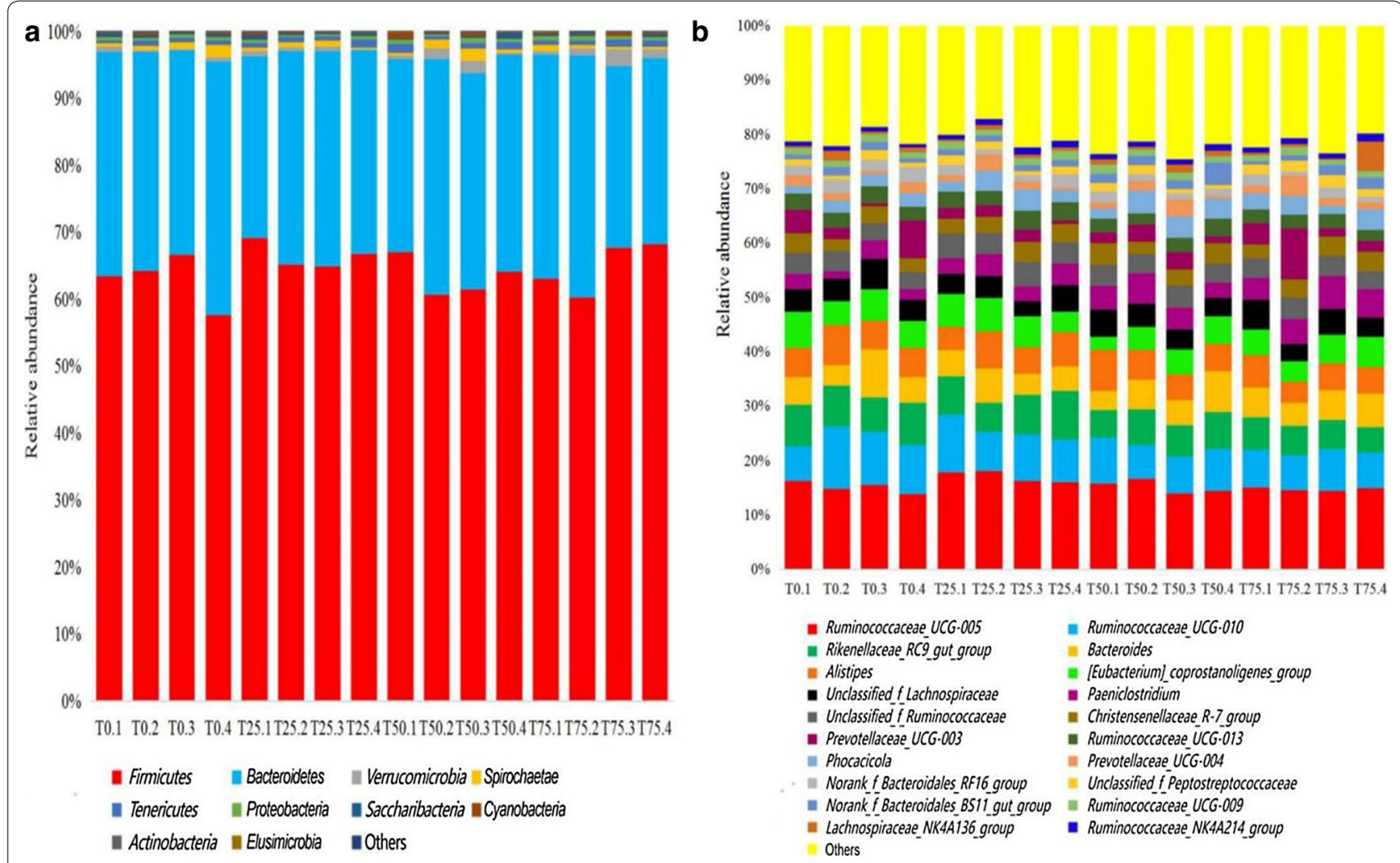

Fig. 6 Relative abundance of fecal bacterial community on the phylum and genus level. Figure 6 a is the relative abundance on the phylum level; Fig. $6 \mathrm{~b}$ is the relative abundance on the genus level. T0: BPS replaces $0 \%$ of WCS; T25: BPS replaces $25 \%$ of WCS; T50: BPS replaces 50\% of WCS; T75: BPS replaces $75 \%$ of WCS. Numbers 1, 2, 3 and 4 in names of samples refer to individual heifers per set of treatment. BPS, Broussonetia papyrifera silage; WCS, whole corn silage

had positive correlation with IL-1 $\beta$ and IL-6 $\left(\mathrm{C}_{\mathrm{XY}}=0.56\right.$, $\mathrm{P}=0.03 ; \mathrm{C}_{\mathrm{XY}}=0.57, \mathrm{P}=0.03$, respectively); Coprococcus_3 had positive correlation with IL-1 $\beta\left(\mathrm{C}_{\mathrm{XY}}=0.69\right.$, $\mathrm{P}=0.004)$; Unclassified_f_peptoccaceae had negative correlation with IL-10 $\left(\mathrm{C}_{\mathrm{XY}}=-0.61, \mathrm{P}=0.02\right)$; Tyzzerella had negative correlation with $\mathrm{IL}-2\left(\mathrm{C}_{\mathrm{XY}}=-0.56\right.$, $\mathrm{P}=0.03)$; Coprococcus_3 had negative correlation with IL-4 $\left(C_{X Y}=-0.57, P=0.03\right)$. For hindgut fermentation parameters, Coprococcus_3 was positively correlated with PA $\left(\mathrm{C}_{\mathrm{XY}}=0.68, \mathrm{P}=0.005\right)$; Peptostreptococcaceae was negatively correlated with $\mathrm{AA}$ and $\mathrm{PA}\left(\mathrm{C}_{\mathrm{XY}}=-0.55\right.$, $\left.\mathrm{P}=0.03 ; \mathrm{C}_{\mathrm{XY}}=-0.61, \mathrm{P}=0.02\right) ;$ Paeniclostridium was negatively correlated with $\mathrm{PA}\left(\mathrm{C}_{\mathrm{XY}}=-0.57, \mathrm{P}=0.03\right)$.

\section{$16 \mathrm{~S}$ function prediction}

$16 \mathrm{~S}$ function prediction was performed via PICRUSt software, which stores a series of databases. By comparing information with different databases, COG information, KEGG Ortholog (KO) information, and pathway information of differential OTUs can be obtained and matched. The abundance of functional category can be calculated according to the abundance of differential OTUs. The results of $16 \mathrm{~S}$ function prediction were shown in Fig. 9. As shown in Fig. 9a, with the increaing of BPS content, the abundance of some COG functions, such as Inorganic ion transport and metabolism, Chromatin structure and dynamics, and Coenzyme transport and metabolism, increased; others, like Cell motility, Cytoskeleton, and Replication, recombination and repair, decreased. In this study, a total of 222 pathways were obtained, and they involved in metabolism, genetic information processing, environmental information processing, and cellular processes; and the first 20 abundant pathways were shown in Fig. 9b.

\section{Discussion}

In the process of cell metabolism, the body will produce a large number of free radicals like reactive oxygen species (ROS), which have a strong oxidation ability. These free radicals have strong toxicity and cause damage to biological macromolecules such as carbohydrates, proteins, lipids, and DNA, and finally leading to oxidative stress and the recession of physiological function, immunity, and production performance, thus causing diseases (Thannickal and Fanburg 2000; Gill and Tuteja 2020). In order to respond to the adverse effects of oxidative stress, 


\section{a \\ Peptostreptococcaceae Paeniclostridium \\ Thermoanaerobacteraceae Unclassified_f Peptoccaceae Tyzzerella Gelria \\ Thermoanaerobacterales Roseburia Alphaproteobacteria Ruminococcaceae Saccharofermentants Coprococcus_3}

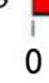

$\square T 0$ T0 $\square$ T25 T50 1 T75

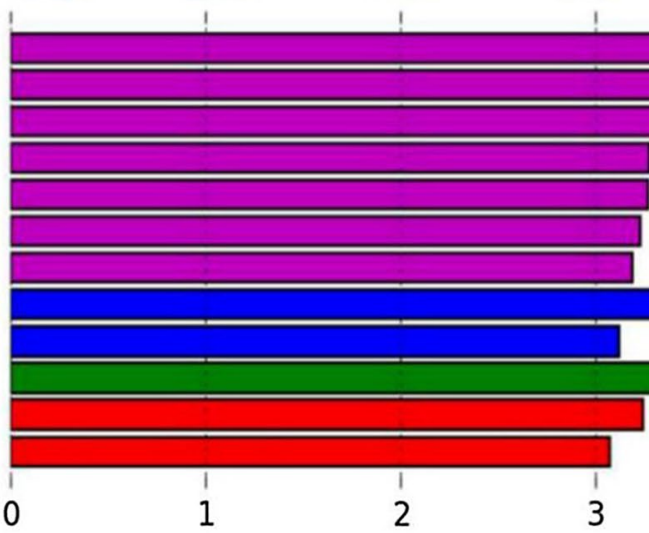

LDA SCORE $(\log 10)$

b

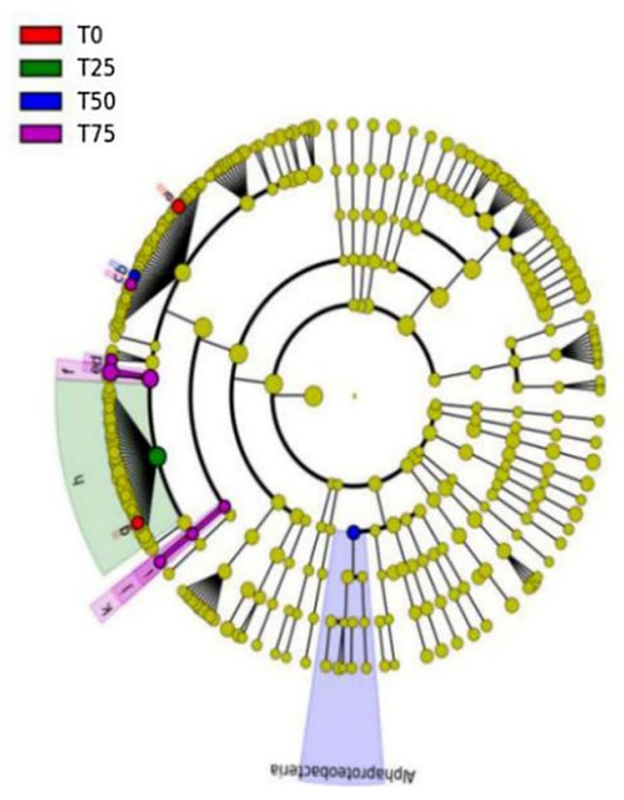

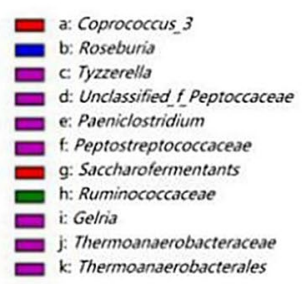

$\mathrm{k}$. Thermoanaerobacterales

Fig. 7 Comparison of microbial variations using the LEfSe online tool. TO: BPS replaces 0\% of WCS; T25: BPS replaces 25\% of WCS; T50: BPS replaces 50\% of WCS; T75: BPS replaces 75\% of WCS. Numbers 1, 2, 3 and 4 in names of samples refer to individual heifers per set of treatment. BPS, Broussonetia papyrifera silage; WCS, whole corn silage

\section{(See figure on next page.)}

Fig. 8 Correlation analyses of differential OTUs with serum anti-oxidant indicators (a), serum immune indicators (b), and hindgut fermentation parameters (c). Each cell contains Pearson correlation coefficient and P-value (within brackets). a MDA, malondialdehyde; SOD, superoxide dismutase; GSH-Px, glutathione peroxidase; CAT, catalase; T-AOC, total antioxidant capacity. b lg, immunoglobulin; IL, interleukin. c AA, acetic acid; PA, propionic acid; IBA, isobutyric acid; BA, butyric acid; IVA, isovaleric acid; VA, valeric acid; $\mathrm{NH}_{3}-\mathrm{N}$, ammoniacal nitrogen

the anti-oxidative defence system (AOS) release various enzymes such as CAT, GSH-Px, and SOD (Prokić et al. 2018). Superoxide dismutase can convert superoxide anion radical $\left(\cdot \mathrm{O}_{2}{ }^{-}\right)$into hydrogen peroxide $\left(\mathrm{H}_{2} \mathrm{O}_{2}\right)$, subsequently, $\mathrm{H}_{2} \mathrm{O}_{2}$ is broken into $\mathrm{H}_{2} \mathrm{O}$ by CAT or GSH-Px
(Olsvik et al. 2005). Malonaldehyde is the final product of lipid peroxidation caused by ROS, the content of MDA can reflect the degree of lipid peroxidation and cell damage in the body, and the increase of MDA content marks the aggravation of cell damage (Esterbauer et al. 1991; Rio 


\begin{tabular}{|c|c|c|c|c|c|c|c|c|c|}
\hline a Peptostreptococcaceae & \multicolumn{2}{|l|}{$\begin{array}{l}0.21 \\
(0.4)\end{array}$} & $\begin{array}{l}0.091 \\
(0.7)\end{array}$ & \multicolumn{2}{|c|}{$\begin{array}{l}-0.089 \\
(0.8)\end{array}$} & \multicolumn{2}{|l|}{$\begin{array}{l}-0.05 \\
0.97\end{array}$} & $\begin{array}{l}-0.29 \\
(0.3)\end{array}$ & \multirow{6}{*}{-0.5} \\
\hline Paeniclostridium & \multicolumn{2}{|c|}{$\begin{array}{l}0.29 \\
(0.3)\end{array}$} & $\begin{array}{l}-0.018 \\
(0.9)\end{array}$ & \multicolumn{2}{|c|}{$\underset{\text { (1) }}{0.011}$} & \multicolumn{2}{|c|}{$\begin{array}{l}-0.008 \\
(0.8)\end{array}$} & $\begin{array}{l}-0.25 \\
(0.4)\end{array}$ & \\
\hline Thermoanaerobacteraceae & \multicolumn{2}{|c|}{$\begin{array}{l}0.03 \\
(0.009)\end{array}$} & $\begin{array}{l}-0.28 \\
(0.3)\end{array}$ & \multicolumn{2}{|c|}{$\begin{array}{l}-0.21 \\
(0.4)\end{array}$} & \multicolumn{2}{|c|}{$\begin{array}{l}0.15 \\
(0.6)\end{array}$} & $\begin{array}{l}-0.29 \\
(0.3)\end{array}$ & \\
\hline Unclassified_f_Peptoccaceae & \multicolumn{2}{|c|}{$\begin{array}{l}0.18 \\
(0.6)\end{array}$} & $\begin{array}{l}-0.18 \\
(0.5)\end{array}$ & \multicolumn{2}{|c|}{-0.2} & \multicolumn{2}{|c|}{$\begin{array}{l}-0.22 \\
(0.4)\end{array}$} & $\begin{array}{l}-0.53 \\
(0.04)\end{array}$ & \\
\hline Tyzzerella & \multicolumn{2}{|c|}{$\begin{array}{l}0.25 \\
(0.4)\end{array}$} & $\begin{array}{l}-0.095 \\
(0.7)\end{array}$ & \multicolumn{2}{|c|}{$\begin{array}{l}-0.13 \\
(0.6)\end{array}$} & \multicolumn{2}{|c|}{$\begin{array}{l}-0.44 \\
(0.09)\end{array}$} & $\begin{array}{l}-0.22 \\
(0.4)\end{array}$ & \\
\hline Gelria & \multicolumn{2}{|c|}{$\begin{array}{c}0.83 \\
(0.009)\end{array}$} & -0.28 & \multicolumn{2}{|c|}{$\begin{array}{l}-0.21 \\
(0.4)\end{array}$} & \multicolumn{2}{|c|}{$\begin{array}{l}0.15 \\
(0.6)\end{array}$} & $\begin{array}{l}-0.29 \\
(0.3)\end{array}$ & \\
\hline Thermoanaerobacterales & $\begin{array}{r}0.63 \\
10.009 \\
\end{array}$ & & $\begin{array}{l}-0.28 \\
(0.3)\end{array}$ & & & $\begin{array}{l}0.15 \\
(0.6)\end{array}$ & & $\begin{array}{l}-0.29 \\
(0.3)\end{array}$ & -0 \\
\hline Roseburia & $\begin{array}{l}-0.24 \\
(0.4)\end{array}$ & & $\begin{array}{l}0.22 \\
(0.4)\end{array}$ & & 98 & $\begin{array}{l}-0.38 \\
(0.1)\end{array}$ & & $\begin{array}{l}0.044 \\
(0.9)\end{array}$ & \\
\hline Alphaproteobacteria & $\begin{array}{l}0.34 \\
(0.2)\end{array}$ & & $\begin{array}{l}0.14 \\
(0.6)\end{array}$ & & & $\begin{array}{l}-0.25 \\
(0.3)\end{array}$ & & $\begin{array}{l}-0.36 \\
(0.2)\end{array}$ & \\
\hline Ruminococcaceae & $\begin{array}{l}-0.07 \\
(0.8)\end{array}$ & & $\begin{array}{l}0.23 \\
(0.4)\end{array}$ & & & $\begin{array}{l}0.45 \\
(0.08)\end{array}$ & & $\begin{array}{l}0.087 \\
(0.7)\end{array}$ & -0.5 \\
\hline Saccharofermentants & $\begin{array}{l}-0.37 \\
(0.2)\end{array}$ & & $\begin{array}{l}0.21 \\
(0.4)\end{array}$ & & & $\begin{array}{l}0.17 \\
(0.5)\end{array}$ & & $\begin{array}{l}0.35 \\
(0.2)\end{array}$ & \\
\hline Coprococcus_3 & $\begin{array}{r}-0.39 \\
(0.1) \\
\end{array}$ & & $\begin{array}{l}0.24 \\
0.4) \\
\end{array}$ & & & $\begin{array}{l}-0.017 \\
(0.9)\end{array}$ & & $\begin{array}{l}0.4 \\
(0.1) \\
\end{array}$ & \\
\hline & $s^{x}$ & & $\Theta^{\circ}$ & $0^{\omega^{3}}$ & & $e^{x}$ & & $0^{\circ}$ & \\
\hline b Peptostreptococcaceae & $\begin{array}{l}0.38 \\
(0.2)\end{array}$ & $\begin{array}{l}-0.45 \\
(0.09)\end{array}$ & $\begin{array}{l}-0.23 \\
(0.4)\end{array}$ & & & $\begin{array}{l}-0.31 \\
(0.3)\end{array}$ & $\begin{array}{l}-0.22 \\
(0.4)\end{array}$ & $\begin{array}{l}-0.33 \\
(0.2)\end{array}$ & \\
\hline Paeniclostridium & $\begin{array}{l}0.42 \\
(0.1)\end{array}$ & $\begin{array}{l}-0.45 \\
(0.09)\end{array}$ & $\begin{array}{l}-0.23 \\
(0.4)\end{array}$ & 10 & & $\begin{array}{l}-0.38 \\
(0.2)\end{array}$ & $\begin{array}{l}-0.14 \\
(0.8)\end{array}$ & $\begin{array}{l}-0.34 \\
(0.2)\end{array}$ & \\
\hline Thermoanaerobacteraceae & $\begin{array}{l}0.097 \\
(0.7)\end{array}$ & $\begin{array}{l}-0.27 \\
(0.3)\end{array}$ & $\begin{array}{l}-0.32 \\
(0.2)\end{array}$ & io & & $\begin{array}{l}-0.22 \\
(0.4)\end{array}$ & $\begin{array}{l}-0.078 \\
(0.8)\end{array}$ & $\begin{array}{l}0.034 \\
(0.9)\end{array}$ & -0.5 \\
\hline Unclassified_f Peptoccaceae & $\begin{array}{l}-0.028 \\
(0.9)\end{array}$ & $\begin{array}{l}-0.13 \\
(0.6)\end{array}$ & $\begin{array}{l}-0.08 \\
(0.8)\end{array}$ & $\begin{array}{l}0 \\
10\end{array}$ & & $\begin{array}{l}-0.15 \\
(0.6)\end{array}$ & $\begin{array}{l}-0.01 \\
(0.02)\end{array}$ & $\begin{array}{l}0.042 \\
(0.9)\end{array}$ & \\
\hline Tyzzerella & $\begin{array}{l}0.31 \\
(0.3)\end{array}$ & $\begin{array}{l}-0.39 \\
(0.2)\end{array}$ & $\begin{array}{l}-0.56 \\
(0.03)\end{array}$ & $0^{\circ}$ & & $\begin{array}{l}-0.33 \\
(0.2)\end{array}$ & $\begin{array}{l}0.096 \\
(0.7)\end{array}$ & $\begin{array}{l}-0.35 \\
(0.2)\end{array}$ & \\
\hline Gelria & $\begin{array}{l}0.097 \\
(0.7)\end{array}$ & $\begin{array}{l}-0.27 \\
(0.3)\end{array}$ & $\begin{array}{l}-0.32 \\
(0.2)\end{array}$ & 10 & & $\begin{array}{l}-0.22 \\
(0.4)\end{array}$ & $\begin{array}{l}-0.078 \\
(0.8)\end{array}$ & $\begin{array}{l}0.034 \\
(0.9)\end{array}$ & \\
\hline Thermoanaerobacterales & $\begin{array}{l}0.097 \\
(0.7)\end{array}$ & $\begin{array}{l}-0.27 \\
(0.3)\end{array}$ & $\begin{array}{l}-0.32 \\
(0.2)\end{array}$ & 0. & & $\begin{array}{l}-0.22 \\
(0.4)\end{array}$ & $\begin{array}{l}-0.078 \\
(0.8)\end{array}$ & $\begin{array}{l}0.034 \\
(0.9)\end{array}$ & -0 \\
\hline Roseburia & $\begin{array}{l}-0.14 \\
(0.6)\end{array}$ & $\begin{array}{l}0.12 \\
(0.7)\end{array}$ & $\begin{array}{l}0.17 \\
(0.5)\end{array}$ & $\begin{array}{l}0.0 \\
10\end{array}$ & & $\begin{array}{l}0.58 \\
(0.02) \\
\end{array}$ & $\begin{array}{l}-0.19 \\
(0.5)\end{array}$ & $\begin{array}{l}-0.18 \\
(0.5)\end{array}$ & \\
\hline Alphaproteobacteria & $\begin{array}{l}0.25 \\
(0.4)\end{array}$ & $\begin{array}{l}-0.26 \\
(0.3)\end{array}$ & $\begin{array}{l}-0.22 \\
(0.4)\end{array}$ & $\stackrel{0}{0}$ & & $\begin{array}{l}0.043 \\
(0.9)\end{array}$ & $\begin{array}{l}-0.19 \\
(0.5)\end{array}$ & $\begin{array}{l}-0.043 \\
(0.9)\end{array}$ & \\
\hline Ruminococcaceae & $\begin{array}{l}-0.28 \\
(0.3)\end{array}$ & $\begin{array}{l}0.042 \\
(0.9)\end{array}$ & $\begin{array}{l}0.078 \\
(0.8)\end{array}$ & $\begin{array}{l}-0 \\
10\end{array}$ & & $\begin{array}{l}0.18 \\
(0.5)\end{array}$ & $\begin{array}{l}0.052 \\
(0.9)\end{array}$ & $\begin{array}{l}0.15 \\
(0.8)\end{array}$ & --0.5 \\
\hline Saccharofermentants & $\begin{array}{l}-0.28 \\
(0.3)\end{array}$ & $\begin{array}{l}0.58 \\
(0.03)\end{array}$ & $\begin{array}{l}0.27 \\
(0.3)\end{array}$ & -0.0 & & $\begin{array}{l}0.57 \\
(0.03)\end{array}$ & $\begin{array}{l}-0.084 \\
(0.8)\end{array}$ & $\begin{array}{l}0.28 \\
(0.4)\end{array}$ & \\
\hline Coprococcus_3 & $\begin{array}{r}-0.22 \\
(0.4) \\
\end{array}$ & $\begin{array}{r}0.89 \\
(0.004) \\
\end{array}$ & $\begin{array}{r}0.48 \\
0.077 \\
\end{array}$ & -0. & & $\begin{array}{l}0.48 \\
(0.09)\end{array}$ & $\begin{array}{l}0.17 \\
(0.8) \\
\end{array}$ & $\begin{array}{l}-0.077 \\
(0.8)\end{array}$ & \\
\hline & 8 & $v^{\circ}$ & $\approx^{2}$ & $\approx$ & & $\sim^{6}$ & $\approx$ & $v^{n}$ & \\
\hline C Peptostreptococcaceae & $\begin{array}{l}-0.55 \\
(0.03)\end{array}$ & $\begin{array}{l}-0.61 \\
(0.02)\end{array}$ & $\begin{array}{c}-0.0021 \\
\text { (1) }\end{array}$ & $\begin{array}{l}-0.44 \\
(0.1)\end{array}$ & $\begin{array}{l}-0.078 \\
(0.8)\end{array}$ & $\begin{array}{l}-0.33 \\
(0.2)\end{array}$ & $\begin{array}{l}0.0073 \\
\text { (1) }\end{array}$ & $\begin{array}{l}0.47 \\
(0.08)\end{array}$ & \\
\hline Paeniclostridium & $\begin{array}{l}-0.51 \\
(0.05)\end{array}$ & $(0.03)$ & $\begin{array}{l}0.12 \\
(0.7)\end{array}$ & $\begin{array}{l}-0.46 \\
(0.08)\end{array}$ & $\begin{array}{l}0.049 \\
(0.9)\end{array}$ & $\begin{array}{l}-0.31 \\
(0.3)\end{array}$ & -0.0093 & $\begin{array}{l}0.48 \\
(0.07)\end{array}$ & \\
\hline Thermoanaerobacteraceae & $\begin{array}{l}-0.32 \\
(0.2)\end{array}$ & $\begin{array}{l}-0.4 \\
(0.1)\end{array}$ & $\begin{array}{l}0.29 \\
(0.3)\end{array}$ & $\begin{array}{l}-0.29 \\
(0.3)\end{array}$ & $\begin{array}{l}0.3 \\
(0.3)\end{array}$ & $\begin{array}{l}-0.18 \\
(0.5)\end{array}$ & $\begin{array}{c}-0.0053 \\
\text { (1) }\end{array}$ & $\begin{array}{l}0.25 \\
(0.4)\end{array}$ & -0.5 \\
\hline Unclassified_f_Peptoccaceae & -0.013 & $\begin{array}{l}-0.048 \\
(0.9)\end{array}$ & $\begin{array}{l}0.24 \\
(0.4)\end{array}$ & $\begin{array}{l}0.15 \\
(0.8)\end{array}$ & $\begin{array}{l}0.34 \\
(0.2)\end{array}$ & $\begin{array}{l}0.29 \\
(0.3)\end{array}$ & $\begin{array}{l}0.47 \\
(0.07)\end{array}$ & $\begin{array}{l}-0.077 \\
(0.8)\end{array}$ & \\
\hline Tyzzerella & $\begin{array}{l}-0.52 \\
(0.05)\end{array}$ & $\begin{array}{l}-0.48 \\
(0.07)\end{array}$ & $\begin{array}{l}0.42 \\
(0.1)\end{array}$ & $\begin{array}{l}-0.4 \\
(0.1)\end{array}$ & $\begin{array}{l}0.35 \\
(0.2)\end{array}$ & $\begin{array}{l}-0.28 \\
(0.3)\end{array}$ & -0.2 & $\begin{array}{l}0.24 \\
(0.4)\end{array}$ & \\
\hline Gelria & $\begin{array}{l}-0.32 \\
(0.2)\end{array}$ & $\begin{array}{r}-0.4 \\
(0.1)\end{array}$ & $\begin{array}{l}0.29 \\
(0.3)\end{array}$ & $\begin{array}{l}-0.29 \\
(0.3)\end{array}$ & $\begin{array}{l}0.3 \\
(0.3)\end{array}$ & $\begin{array}{l}-0.18 \\
(0.5)\end{array}$ & $\begin{array}{l}-0.0053 \\
\text { (1) }\end{array}$ & $\begin{array}{l}0.25 \\
(0.4)\end{array}$ & -0 \\
\hline Thermoanaerobacterales & $\begin{array}{l}-0.32 \\
(0.2)\end{array}$ & $(0.1)$ & $\begin{array}{l}0.29 \\
(0.3)\end{array}$ & $\begin{array}{l}-0.29 \\
(0.3)\end{array}$ & $\begin{array}{l}0.3 \\
(0.3)\end{array}$ & $\begin{array}{l}-0.18 \\
(0.5)\end{array}$ & -0.0053 & $\begin{array}{l}0.25 \\
(0.4)\end{array}$ & -0 \\
\hline Roseburia & -0.0072 & $\begin{array}{l}0.081 \\
(0.8)\end{array}$ & $\begin{array}{l}-0.11 \\
(0.7)\end{array}$ & $\begin{array}{l}-0.057 \\
(0.8)\end{array}$ & $\begin{array}{l}-0.12 \\
(0.7)\end{array}$ & $\begin{array}{l}-0.14 \\
(0.6)\end{array}$ & $\begin{array}{l}-0.039 \\
(0.9)\end{array}$ & $\begin{array}{l}-0.0077 \\
\text { (1) }\end{array}$ & \\
\hline Alphaproteobacteria & $\begin{array}{l}-0.34 \\
(0.2)\end{array}$ & $\begin{array}{l}-0.38 \\
(0.2)\end{array}$ & $\begin{array}{l}-0.19 \\
(0.5)\end{array}$ & $\begin{array}{l}-0.12 \\
(0.7)\end{array}$ & $\begin{array}{l}-0.055 \\
(0.8)\end{array}$ & $\begin{array}{l}-0.088 \\
(0.8)\end{array}$ & $\begin{array}{l}0.12 \\
(0.7)\end{array}$ & $\begin{array}{l}0.078 \\
(0.8)\end{array}$ & \\
\hline Ruminococcaceae & $\begin{array}{l}-0.015 \\
\text { (1) }\end{array}$ & $\begin{array}{l}-0.13 \\
(0.6)\end{array}$ & $\begin{array}{l}-0.43 \\
(0.1)\end{array}$ & $\begin{array}{l}-0.13 \\
(0.8)\end{array}$ & $\begin{array}{l}-0.49 \\
(0.07)\end{array}$ & $\begin{array}{l}-0.25 \\
(0.4)\end{array}$ & $\begin{array}{l}-0.17 \\
(0.5)\end{array}$ & $\begin{array}{l}0.16 \\
(0.6)\end{array}$ & -0.5 \\
\hline Saccharofermentants & $\begin{array}{l}0.35 \\
(0.2)\end{array}$ & $\begin{array}{l}0.4 \\
(0.1)\end{array}$ & $\begin{array}{l}-0.34 \\
(0.2)\end{array}$ & $\begin{array}{l}0.47 \\
(0.07)\end{array}$ & $\begin{array}{l}-0.23 \\
(0.4)\end{array}$ & $\begin{array}{l}0.27 \\
(0.3)\end{array}$ & $\begin{array}{l}-0.011 \\
\text { (1) }\end{array}$ & $\begin{array}{l}-0.42 \\
(0.1)\end{array}$ & \\
\hline Coprococcus_3 & $\begin{array}{l}0.52 \\
(0.055) \\
\end{array}$ & $\begin{array}{r}0.88 \\
(0.005) \\
\end{array}$ & $\begin{array}{l}-0.052 \\
(0.9)\end{array}$ & $\begin{array}{r}0.51 \\
(0.05) \\
\end{array}$ & $\begin{array}{c}0.0071 \\
(1)\end{array}$ & $\begin{array}{r}0.48 \\
(0.07) \\
\end{array}$ & $\begin{array}{l}0.088 \\
(0.8) \\
\end{array}$ & $\begin{array}{l}-0.48 \\
(0.077) \\
\end{array}$ & \\
\hline & $r^{\circ}$ & $8^{\circ}$ & $\theta$ & $8^{x}$ & $w$ & $s$ & $+x^{2}$ & के & \\
\hline
\end{tabular}


(See figure on next page.)

Fig. 9 Heatmap of 16S rRNA gene-predicted functional (a) and pathway-predicted (b) profiles obtained via Phylogenetic Investigation of Communities by Reconstruction of Unobserved States (PICRUSt). TO: BPS replaces 0\% of WCS; T25: BPS replaces 25\% of WCS; T50: BPS replaces 50\% of WCS; T75: BPS replaces 75\% of WCS. Numbers 1, 2, 3 and 4 in names of samples refer to individual heifers per set of treatment. BPS, Broussonetia papyrifera silage; WCS, whole corn silage

et al. 2005; Castillo et al. 2006). Total antioxidant capacity is a comprehensive indicator to measure the antioxidant capacity in vivo, reflecting the dynamic balance between pro-oxidants and anti-oxidants, as well as the free radical metabolism state (Ghiselli et al. 2000). In this study, the MDA content of T25, T50, and T75 are lower than T0, indicating that BPS can enhance the resistance of lipid peroxidation in experimental heifers.

Interleukins (IL) are a group of cytokines which are mainly secreted by leukocytes, playing important roles in immune response and tissue repair. IL- $1 \beta$ is a proinflammatory cytokine which features in inflammatory and infectious diseases, leading immune cell recruitment and bacterial clearance eventually (Zhang et al. 2019). IL-4 is an anti-inflammatory cytokine, which is related to regulating immune cells, cancer and trophic responses (Granja et al. 2009; Shamoun et al. 2018; Oviedo-Boyso et al. 2007) found that when cows develop bacteria-induced inflammation, the levels of pro-inflammatory cytokines like IL- $1 \beta$, IL- 2 and IL- 6 in the body increased, and the overexpression of pro-inflammatory factor caused tissue damage. A large number of studies showed that IL-4 and IL-10 can inhibit the secretion of pro-inflammatory cytokines like IL-1 $\beta$ and IL-6 (Cawston et al. 1996; Mak and Saunders 2006; Borghaei et al. 2010). The above findings suggest that an increase in IL-1 $\beta$ or a decrease in IL-4 may indicate inflammation. In the present study, the IL- $1 \beta$ content of T25, T50, and T75 decreased significantly compared with T0; the IL- 4 and IgA content of T25, T50, and T75 increased, demonstrating that BPS has the potential to improve immunity of heifers. The immunomodulatory function of Broussonetia papyrifera is derived from its bioactive substances, similar reports had been reported in other woody forages like Moringa oleifera and Neolamarckia cadamba (Pandey and Negi 2016; Valdivié-Navarro et al. 2020).

Corn is a starch-rich feed material. Starch that has not been digested by rumen microorganisms and small intestinal enzymes will enter the hindgut and continue to ferment, leading to the decreasing of fecal $\mathrm{pH}$ value (Petri et al. 2019). Superfluous fermentable carbohydrates can cause hindgut acidosis (Sulzberger et al. 2016). In the present study, the fecal $\mathrm{pH}$ value of $\mathrm{TO}$ is lower than the other three treatments, presumably because the fermentable carbohydrates content of T0 is the highest among the four treatments. VFAs mainly come from the decomposition of carbohydrates. Rumen microorganisms can convert carbohydrates such as starch, cellulose, and soluble sugar into pyruvate, which can be converted into different VFAs due to different metabolic pathways. Moreover, VFAs play important roles in maintaining the integrity of intestinal epithelial morphology and function (Sato et al. 2009; Missotten et al. 2010). Fecal $\mathrm{NH}_{3}-\mathrm{N}$ is derived from the hydrolysis of amino acids and proteins by proteolytic enzyme and deaminase; and is correlated with $\mathrm{N}$ intake strongly (Weiss et al. 2009). In addition, according to another research, when animals ingest diets containing high NDF, a large number of microorganisms related to fiber degradation in the rumen take advantage of $\mathrm{NH}_{3}-\mathrm{N}$ as the main nitrogen source for metabolism, resulting in the decrease of $\mathrm{NH}_{3}-\mathrm{N}$ in the rumen and intestinal track (Hristov and Ropp 2003). In this study, compared with $\mathrm{T} 0, \mathrm{NH}_{3}-\mathrm{N}$ content in the other three treatments occurred no significant changes. In conclusion, the substitution of WCS for BPS had no significant effect on the intestinal fermentation parameters of heifers.

Gastrointestinal tract is an important habitat for bacteria, intestinal bacteria play important roles in the health and growth of host. Learning the microbial community structure of feces is important for reducing foodborne pathogens through diets changes. In the present study, no significant differences were presented in Shannon index, Ace index, and Chao index, indicating the BPS had no obvious effect on $\alpha$-diversity, and the result is similar to another two studies. Sun et al. (2017) and Li et al. (2017) fed cows and steers with ensiled $M$. oleifera and ensiled mulberry leaves respectively, finding that there were no conspicuous differences on $\alpha$-diversity. According to Fig. 1 and $87.46 \%$ of OTU in the four treatments is uniform. The results above demonstrate that the component of coarse fodder cannot affect the fecal bacterial community significantly.

On the phylum level, the dominant phyla is Firmicutes and Bacteroidetes, according to a report, the two phyla are predominant in the large intestine of numerous mammals such as human being, ruminant, pig, and mouse (Ban-Tokuda et al. 2017). Firmicutes and Bacteroidetes contain various carbohydrate utilizing enzymes, play a vital part in fiber degradation (Xu et al. 2019). The addition of BPS has no effect on the species of dominant phyla in feces, but the relative abundance of dominant phyla 
a

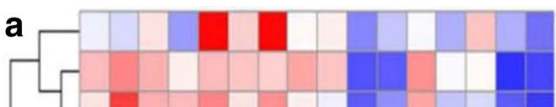

Cell cycle control, cell division, chromosome partitioning

Replication, recombination and repair

Energy production and conversion

Coenzyme transport and metabolism

Nucleotide transport and metabolism

Translation, ribosomal structure and biogenesis

Cell wall/membrane/envelope biogenesis

Posttranslational modification, protein turnover, chaperones

Carbohydrate transport and metabolism

Cell motility

Signal transduction mechanisms

Amino acid transport and metabolism

Translation, ribosomal structure and biogenesis

Defense mechanisms

Chromatin structure and dynamics

Function unknown

Inorganic ion transport and metabolism

General function prediction only

RNA processing and modification

Secondary metabolites biosynthesis, transport and catabolism

Lipid transport and metabolism

Intracellular trafficking, secretion, and vesicular transport

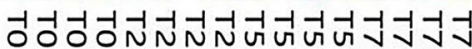

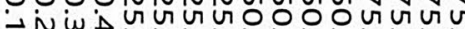

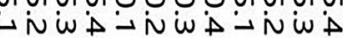

b

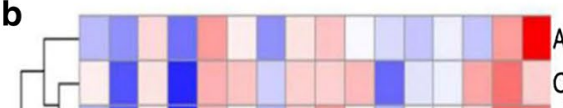

$A B C$ transporters

Cysteine and methionine metabolism

Porphyrin and chlorophyll metabolism

Two-component system

Oxidative phosphorylation

Pyruvate metabolism

Starch and sucrose metabolism

Amino sugar and nucleotide sugar metabolism

Methane metabolism

0

Phenylalanine, tyrosine and tryptophan biosynthesis

Oxidative phosphorylation

Carbon fixation pathways in prokaryotes

Alanine, aspartate and glutamate metabolism

Mismatch repair

Ribosome

Pyrimidine metabolism

Homologous recombination

Purine metabolism

Aminoacyl-tRNA biosynthesis

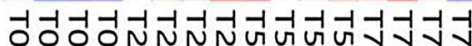

-

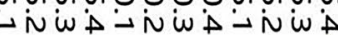


can be improved. Verrucomicrobia is the third dominant phylum, with the increasing of BPS content, the relative abundance of this phylum improves accordingly. A previous study found that Verrucomicrobia has the potential to induce and regulate immunity, it may be a target of intestinal microbial intervention to improve the regulation of immunity (Lindenberg et al. 2019). The increasing of Verrucomicrobia may be associated with improved intestinal immunity. On the genus level, the dominant phyla is Ruminococcaceae_UCG-005, Ruminococcaceae_ UCG-010, and Rikenellaceae_RC9_gut_group. The result is different from another two studies (Li et al. 2012; Zhao et al. 2017). In addition, the dominants of different treatments in this study present significant difference, indicating diets has a great influence on the genus level of fecal bacterial community of heifers (Kim et al. 2014). According to $\mathrm{Li}$ et al. (2018), with the severity of diarrhea, the relative abundance of Ruminococcaceae_UCG-005, and Rikenellaceae_RC9_gut_group in the musk deer feces decrease, in this study, the relative abundance of above two genera in T25 is higher than that in T0, T50, and T75, indicating that moderate BPS may be able to relieve diarrhea, however, this deserves further study.

LEfSe analysis is an analytical tool for the discovery and interpretation of high-dimensional data biomarker. It emphasizes statistical significance and biological correlation, and was able to look for biomarkers that differed statistically from group to group. In this study, 12 differential OTUs including one class, one order, three families, and seven genera are obtained. Paeniclostridium is considered a potential pathogen, it may be related to soft tissue infection and toxic shock (Kim et al. 2017). Gelria (Thermoanaerobacterales Order, Thermoanaerobacteraceae Family) is known to be related to the metabolism of VFAs (FitzGerald et al. 2019). Roseburia is a common butyrate-producing bacteria in the intestinal tract (Hatziioanou et al. 2013; Sheridan et al. 2019). Ruminococcaceae are common in both rumen and hindgut of ruminants, playing important parts in degrading starch and cellulose (Zhang et al. 2020). In another study, Han et al. (2018) found that Ruminococcaceae is related to the balance of Treg/ Th17, suggesting that Ruminococcaceae may be related to the immune system. Reports and researches about function of the other differential OTUs is limited, however, these differential OTUs can be investigated as biomarkers in depth. As we can see in Fig. 5a, Gelria is positively correlated with MDA content, and shows a weak negative correlation with SOD, GSH-Px, and T-AOC, thus, it can be researches as a potential antioxidant biological target. Another thing worth noting is shown in Fig. 5b, Coprococcus_3 is positively correlated with IL-1 $\beta$ while negatively correlated with IL-4.
We have described in the preceding text that IL-1 $\beta$ is a proinflammatory cytokine, and IL-4 can inhibit its secretion. Therefore, it can be speculated that the increasing of Coprococcus_3 indicates the occurrence of inflammation.

PICRUSt is an analysis method in order to predict the gene function profile of archaea and bacteria based on the measured bacterial genome of $16 \mathrm{~S}$ rRNA sequence. As shown in Fig. 6a, BPS inhibits carbohydrate transport and metabolism, and promotes amino acid transport and metabolism; the metabolites of carbohydrate and amino acid in the hindgut is VFA and $\mathrm{NH}_{3}-\mathrm{N}$, respectively. Presumably, the change of bacterial community causes the change of gene function abundance, thereby causing the change of metabolites. As shown in Fig. 6b, the abundance of Methane metabolism decreases with the increasing of BPS content, may indicating BPS can reduce methane production; and this confirm the previous point of view.

In conclusion, this research reveals that replace WCS with a certain proportion of BPS might benefit the gut health of Holstein heifers; and the BPS content has significant impacts on fecal bacterial community. In-depth research, 12 differential OTUs are obtained in the four treatments, and they have correlation with some indicators of serum and hindgut to some extent. These differential OTUs can be researched as potential biomarkers in order to observe the changes in healthy status. Finally, we find that BPS changes the abundance of genes and pathways related to various life activities.

\section{Acknowledgements \\ The author is very grateful to Guangdong Yantang Dairy Co., Ltd.}

\section{Authors' contributions}

$H T, Y C, B S, N Z$ and DL conceived and designed the study; HT, YC, NZ, YG, MD and $\mathrm{GL}$ performed the experiments; $\mathrm{YL}$ and MD organized the database and performed the statistical analysis; and $\mathrm{HT}, \mathrm{YC}$ wrote the manuscript. All authors read and approved the final manuscript.

\section{Funding}

This research was funded by Guangdong Natural Science Foundation of China (2017A030313158), Modern Agricultural Industrial Technology System of Guangdong Province (2019KJ127), Guangdong Basic and Applied Basic Research Foundation of China (2019B1515210020), and Guangdong Provincial Promotion Project on Preservation and Utilization of Local Breed of Livestock and Poultry (No.2018-143)

\section{Availability of data and materials}

The sequences in this study were submitted to the Sequence Read Archive (SRA) and a BioProject number PRJNA594421 was obtained.

Ethics approval and consent to participate Not applicable.

Consent for publication

Not applicable.

Competing interests

The authors declare that they have no competing interests. 
Received: 13 October 2020 Accepted: 21 October 2020

Published online: 31 October 2020

\section{References}

AOAC (2002) Official methods of analysis of the Association of Official Analytical Chemists, 17th edn. AOAC International, Gaithersburg

Araújo MJ, de Miranda HH, Marques CAT, Batista IL, Carvalho FJV, Jácome DLdeS, Edvan RL, e Silva TPD, Bezerra LR, Lima AGVdeO, Oliveira RL (2019) Effect of replacing ground corn with Parkia platycephala pod meal on the performance of lactating Anglo-Nubian goats. Anim Feed Sci Tech 258:114313. https://doi.org/10.1016/j.anifeedsci.2019.114313

Ban-Tokuda T, Maekawa S, Miwa T, Ohkawara S, Matsui H (2017) Changes in faecal bacteria during fattening in finishing swine. Anaerobe 47:188-193. https://doi.org/10.1016/j.anaerobe.2017.06.006

Borghaei RC, Rawlings PL, Mochan E (2010) Interleukin-4 suppression of interleukin-1-induced transcription of collagenase (MMP-1) and stromelysin 1 (MMP-3) in human synovial fibroblasts. Arthritis Rheumatol 41:1398-1406.

Broderick GA, Kang JH (1980) Automated simultaneous determination of ammonia and total amino acids in ruminal fluid and in vitro media. J Dairy Sci 63:64-75. https://doi.org/10.3168/jds.S0022-0302(80)82888-8

Castillo C, Hernández J, Valverde I, Pereira V, Sotillo J, López-Alonso M, Benedito $J$ (2006) Plasma malonaldehyde (MDA) and total antioxidant status (TAS) during lactation in dairy cows. Res Vet Sci 80:133-139. https://doi. org/10.1016/j.rvsc.2005.06.003

Cawston TE, Ellis AJ, Bigg H, Curry V, Lean E, Ward D (1996) Interleukin-4 blocks the release of collagen fragments from bovine nasal cartilage treated with cytokines. BBA-Mol Cell Res 1314:226-232.

Dong L, Liu J, Zhong Z, Wang S, Wang H, Huo Y, Wei Z, Yu L (2019) Dietary tea tree oil supplementation improves the intestinal mucosal immunity of weanling piglets. Anim Feed Sci Tech 255:114209. https://doi. org/10.1016/j.anifeedsci.2019.114209

Dong W, Wang Q, Chen J, Liu L, Zhang S (2020) Apparent total tract digestibility of nutrients and the digestible and metabolizable energy values of five unconventional feedstuffs fed to growing pigs. J Appl Anim Res 47(1):273-279. https://doi.org/10.1080/09712119.2019.1625778

Erwin ES, Marco GJ, Emery EM (1961) Volatile fatty acid analyses of blood and rumen fluid by gas chromatography. J Dairy Sci 44(9):1768-1771.

Esterbauer H, Schaur RJ, Zollner H (1991) Chemistry and biochemistry of 4-hydroxynonenal, malonaldehyde and related aldehydes. Free Radical Bio Med 11:81-128. https://doi.org/10.1016/0891-5849(91)90192-6

Fernández C, Pérez-Baena I, Marti JV, Palomares JL, Jorro-Ripoll J, Segarra JV (2019) Use of orange leaves as a replacement for alfalfa in energy and nitrogen partitioning, methane emissions and milk performance of murciano-granadina goats. Anim Feed Sci Tech 247:103-111. https://doi. org/10.1016/j.anifeedsci.2018.11.008

FitzGerald JA, Wall DM, Jackson SA, Murphy JD, Dobson ADW (2019) Trace element supplementation is associated with increases in fermenting bacteria in biogas mono-digestion of grass silage. Renew Energ 138:980-986. https://doi.org/10.1016/j.renene.2019.02.051

Ghiselli A, Serafini M, Natella F, Scaccini C (2000) Total antioxidant capacity as a tool to assess redox status: critical view and experimental data. Free Radical Bio Med 29:1106-1114. https://doi.org/10.1016/S0891-5849(00)00394 $-4$

Gill SS, Tuteja N (2020) Reactive oxygen species and antioxidant machinery in abiotic stress tolerance in crop plants. Plant Physiol Bioch 48:909-930. https://doi.org/10.1016/j.plaphy.2010.08.016

Granja MG, Gomes-Braga LE, de Oliveira RM, de Mello-Silva E, Gonçalvesde-Albuquerque CF, Silva AR, de Castro-Faria-Neto HC, dos Santos AA, Giestal-de-Araujo E (2009) IGF-1 and IGF-1R modulate the effects of IL-4 on retinal ganglion cells survival: The involvement of M1 muscarinic receptor. Biochem Biophy Res Co 519:53-60.

Guarner F (2007) Role of intestinal flora in health and disease. Nutr Hosp Suppl 2:14-19

Guo M, Wang M, Deng H, Zhang X, Wang Z (2013) A novel anticancer agent Broussoflavonol $B$ downregulates estrogen receptor (ER)-a36 expression and inhibits growth of ER-negative breast cancer MDA-MB-231 cells. Eur J Pharmacol 714:56-64.
Han Q, Wu Z, Huang B, Sun L, Ding C, Yuan S, Zhang Z, Chen Y, Hu C, Zhou L, Liu J, Huang Y, Liao J, Yuan M (2016) Extraction, antioxidant and antibacterial activities of Broussonetia papyrifera fruits polysaccharides. Int J Biol Macromol 92:116-124. https://doi.org/10.1016/j.ijbiomac.2016.06.087

Han L, Jin H, Zhou L, Zhang X, Fan Z, Dai M, Lin Q, Huang F, Xuan L, Zhang H, Liu Q (2018) Intestinal Microbiota at Engraftment Influence Acute GraftVersus-Host Disease via the Treg/Th17 Balance in Allo-HSCT Recipients. Front Immunol 9:669. https://doi.org/10.3389/fimmu.2018.00669

Hatziioanou D, Mayer MJ, Duncan SH, Flint HJ, Narbad A (2013) A representative of the dominant human colonic Firmicutes, Roseburia faecis M72/1, forms a novel bacteriocin-like substance. Anaerobe 23:5-8. https://doi. org/10.1016/j.anaerobe.2013.07. 006

He X, Yin H, Han L, Cui R, Fang C, Huang G (2019) Effects of biochar size and type on gaseous emissions during pig manure/wheat straw aerobic composting: Insights into multivariate-microscale characterization and microbial mechanism. Bioresour Technol 271:375-382. https://doi. org/10.1016/j.biortech.2018.09.104

Hristov AN, Ropp JK (2003) Effect of dietary carbohydrate composition and availability on utilization of ruminal ammonia nitrogen for milk protein synthesis in dairy cows. J Dairy Sci 86:2416-2427. https://doi.org/10.3168/ jds.S0022-0302(03)73836-3

Hukerdi YJ, Nasri MHF, Rashidi L, Ganjkhanlou M, Emami A (2019) Effects of dietary olive leaves on performance, carcass traits, meat stability and antioxidant status of fattening Mahabadi male kids. Meat Sci 153:2-8. https://doi.org/10.1016/j.meatsci.2019.03.002

Khorsandi S, Riasi A, Khorvash M, Hashemzadeh F (2019) Nutrients digestibility, metabolic parameters and milk production in postpartum Holstein cows fed pomegranate (Punica granatum L.) by-products silage under heat stress condition. Anim Feed Sci Tech 255:114213. https://doi. org/10.1016/j.anifeedsci.2019. 114213

Kim JY, Kim YB, Song SH, Chung W, Lee C, Ahn SW, Lee SH, Jung MY, Kim T, Nam Y, Roh SW (2017) Genomic analysis of a pathogenic bacterium, Paeniclostridium sordellii CBA7122 containing the highest number of rRNA operons, isolated from a human stool sample. Front Pharmacol 8:840. https://doi.org/10.3389/fphar.2017.00840

Kim M, Kim J, Kuehn LA, Bono JL, Berry ED, Kalchayanand N (2014) Investigation of bacterial diversity in the feces of cattle fed different diets. J Anim Sci 92:683-694. https://doi.org/10.2527/jas.2013-6841

Li Y, Hu L, Xue G, Liu H (2012) Comparison of bacterial diversity in large intestine of Xiangxi yellow cattle (Bos taurus) associated with different diet: Fresh Miscanthus sinensis and mixed forage. Afr J Microbiol Res 6:5965-5974. https://doi.org/10.5897/AJMR12.616

Li Y, Meng Q, Zhou B, Zhou Z (2017) Effect of ensiled mulberry leaves and sun-dried mulberry fruit pomace on the fecal bacterial community composition in finishing steers. BMC Microbiol 17:97. https://doi.org/10.1186/ s12866-017-1011-9

Li Y, Hu X, Yang S, Zhou J, Qi L, Sun X, Fan M, Xu S, Cha M, Zhang M, Lin S, Liu S, Hu D (2018) Comparison between the fecal bacterial microbiota of healthy and diarrheic captive musk deer. Front Microbiol 9, 300. https:// doi.org/10.3389/fmicb.2018.00300

Lindenberg F, Krych L, Fielden J, Kot W, Frokiaer H, van Galen G, Nielsen DS, Hansen AK (2019) Expression of immune regulatory genes correlate with the abundance of specific Clostridiales and Verrucomicrobia species in the equine ileum and cecum. Sci Rep-UK 9:12674. https://doi.org/10.1038/ s41598-019-49081-5

Liu J, Wang H, Lin L, Miao C, Zhang Y, Zhou B (2019) Intestinal barrier damage involved in intestinal microflora changes in fluoride-induced mice. Chemosphere 234:409-418. https://doi.org/10.1016/j.chemospher e.2019.06.080

MakTW, Saunders ME (2006) Cytokines and cytokine receptors in the immune response. Academic Press, New York

Mei RQ, Wang YH, Du GH, Liu GM, Zhang L, Cheng YX (2009) Antioxidant lignans from the fruits of Broussonetia papyrifera. J Nat Prod 72:621-625. https://doi.org/10.1021/np800488p

Missotten JA, Michiels J, Ovyn A, Smet S, Dierick NA (2010) Fermented liquid feed for pigs. Arch Anim Nutr 64:437-466. https://doi.org/10.1080/17450 39X.2010.512725

Olsvik PA, Kristensen T, Waagbø R, Rosseland BO, Tollefsen K-E, Baeverfiord G, Berntssen MHG (2005) mRNA expression of antioxidant enzymes (SOD, CAT and GSH-Px) and lipid peroxidative stress in liver of Atlantic salmon 
(Salmo salar) exposed to hyperoxic water during smoltification. Comp Biochem Phys C 141:314-323. https://doi.org/10.1016/j.cbpc.2005.07.009

Oviedo-Boyso J, Valdez-Alarcón JJ, Cajero-Juárez M, Ochoa-Zarzosa A, López-Meza JE, Bravo-Patiño A, Baizabal-Aguirre VM (2007) Innate immune response of bovine mammary gland to pathogenic bacteria responsible for mastitis. J Infection 54:399-409. https://doi.org/10.1016/j. jinf.2006.06.010

Pandey A, Negi PS (2016) Traditional uses, phytochemistry and pharmacological properties of Neolamarckia cadamba: A review. J Ethnopharmacol 181:118-135. https://doi.org/10.1016/j.jep.2016.01.036

Peng X, Liu H, Chen P, Tang F, Hu Y, Wang F, Pi Z, Zhao M, Chen N, Chen H, Zhang X, Yan X, Liu M, Fu X, Zhao G, Yao P, Wang L, Dai H, Li X, Xiong W, Xu W, Zhen H, Yu H, Shen S (2019) A chromosome-scale genome assembly of paper mulberry (Broussonetia papyrifera) provides new insights into its forage and papermaking usage. Mol Plant 12:661-677. https://doi. org/10.1016/j.molp.2019.01.021

Peng K, Wang G, Wang Y, Chen B, Sun Y, Mo W, Li G, Huang Y (2020) Condensed tannins enhanced antioxidant capacity and hypoxic stress survivability but not growth performance and fatty acid profile of juvenile Japanese seabass (Lateolabrax japonicus). Anim Feed Sci Tech 269:114671.

Petri RM, Münnich M, Zebeli Q, Klevenhusen F (2019) Graded replacement of corn grain with molassed sugar beet pulp modulates the fecal microbia community and hindgut fermentation profile in lactating dairy cows. J Dairy Sci 102:5019-5030. https://doi.org/10.3168/jds.2018-15704

Prokić MD, Petrović TG, Gavrić JP, Despotović SG, Gavrilović BR, Radovanović TB, Faggio C, Saičić ZS (2018) Comparative assessment of the antioxidative defense system in subadult and adult anurans: A lesson from the Bufotes viridis toad. Zoology 130:30-37. https://doi.org/10.1016/j.zool.2018.08.001

Rio DD, Stewart AJ, Pellegrini N (2005) A review of recent studies on malondialdehyde as toxic molecule and biological marker of oxidative stress. Nutr Metab Cardiovas 15:316-328. https://doi.org/10.1016/j.numec d.2005.05.003

Sato H, Shiogama Y (2009) Fecal excretion of alcohols and organic anions in neonatal dairy calves. Anim Sci J 80:171-175. https://doi.org/10.111 1/j.1740-0929.2008.00609.x

Shamoun L, Skarstedt M, Andersson RE, Wågsäter D, Dimberg J (2018) Association study on IL-4, IL-4Ra and IL-13 genetic polymorphisms in Swedish patients with colorectal cancer. Clin Chim Acta 487:101-106. https://doi. org/10.1016/j.cca.2018.09.024

Sheridan PO, Martin JC, Minton NP, Flint HJ, O'Toole PW, Scott KP (2019) Heterologous gene expression in the human gut bacteria Eubacterium rectale and Roseburia inulinivorans by means of conjugative plasmids. Anaerobe 59:131-140. https://doi.org/10.1016/j.anaerobe.2019.06.008

Sohn HY, Kwon CS, Son KH (2010) Fungicidal effect of prenylated flavonol, papyriflavonol A, isolated from Broussonetia papyrifera (L.) vent. against Candida albicans. J Microbiol Biotechn 20:1397-1402.

Sulzberger SA, Kalebich CC, Melnichenko S, Cardoso FC (2016) Effects of clay after a grain challenge on milk composition and on ruminal, blood, and fecal pH in Holstein cows. J Dairy Sci 99:8028-8040.

Sun J, Liu S, Zhang C, Yu L, Bi J, Zhu F, Yang Q (2012) Chemical composition and antioxidant activities of Broussonetia papyrifera fruits. PLoS ONE 7:e32021. https://doi.org/10.1371/journal.pone.0032021

Sun J, Zeng B, Chen Z, Yan S, Wang W, Sun B, He Q, Chen X, Chen T, Jiang Q, X Q, Zhang $Y$ (2017) Characterization of faecal microbial communities of dairy cows fed diets containing ensiled Moringa oleifera fodder. Sci RepUK 7:41403. https://doi.org/10.1038/srep41403

Thannickal VJ, Fanburg BL (2000) Reactive oxygen species in cell signaling. Am J Physiol-lung C 279:1005-1028
Valdivié-Navarro M, Martínez-Aguilar Y, Mesa-Fleitas O, Botello-León A, Betancur-Hurtado C, Velázquez-Martí B (2020) Review of Moringa oleifera as forage meal (leaves plus stems) intended for the feeding of non-ruminant animals. Anim Feed Sci Tech 260:1 14338. https://doi.org/10.1016/j.anife edsci.2019.114338

Van Soest PV, Robertson JB, Lewis BA (1991) Methods for dietary fiber, neutral detergent fiber, and nonstarch polysaccharides in relation to animal nutrition. J Dairy Sci 74:3583-3597. https://doi.org/10.3168/jds.S0022 $-0302(91) 78551-2$

Wang L, Son HJ, Xu ML, Hu JH, Wang MH (2010) Anti-inflammatory and anticancer properties of dichloromethane and butanol fractions from the stem bark of Broussonetia papyrifera. J Korean Soc Appl Bi 53:297-303

Weiss WP, Willett LB, St-Pierre NR, Borger DC, McKelvey TR, Wyatt DJ (2009) Varying forage type, metabolizable protein concentration, and carbohydrate source affects manure excretion, manure ammonia, and nitrogen metabolism of dairy cows. J Dairy Sci 92:5607-5619. https://doi. org/10.3168/jds.2009-2248

Xie B, Wang PJ, Yan ZW, Ren YS, Dong KH, Song ZP, Zhang JX, Zhang CX (2018) Growth performance, nutrient digestibility, carcass traits, body composition, and meat quality of goat fed Chinese jujube (Ziziphus Jujuba Mill) fruit as a replacement for maize in diet. Anim Feed Sci Tech 246:127-136.

Xie Y, Chen Z, Wang D, Chen G, Sun X, He Q, Luo J, Chen T, Xi Q, Zhang Y, Sun $J(2020)$ Effects of fermented herbal tea residues on the intestinal microbiota characteristics of Holstein heifers under heat stress. Front Microbiol 11:1014.

Xu ML, Wang L, Hu JH, Lee SK, Wang MH (2010) Antioxidant activities and related polyphenolic constituents of the methanol extract fractions from Broussonetia papyrifera stem bark and wood. Food Sci Biotechnol 19:677-682. https://doi.org/10.1007/s10068-010-0095-X

Xu R, Lu Y, Wang J, Liu J, Su Y, Zhu W (2019) Effects of the different dietary fibers on luminal microbiota composition and mucosal gene expression in pig colons. J Funct Food 59:71-79.

Yao L, Yang H, Yoo CG, Meng X, Li M, Pu Y, Ragauskas AJ, Sykes RW (2017) Adsorption of cellobiohydrolases I onto lignin fractions from dilute acid pretreated Broussonetia papyrifera. Bioresource Technol 244:957-962.

Zhai S, Li M, Li M, Zhang X, Ye H, Lin Z, Wang W, Zhu Y, Yang L (2020) Effect of dietary Moringa stem meal level on growth performance, slaughter performance and serum biochemical parameters in geese. J Anim Physiol An N 104(1):126-135. https://doi.org/10.1111/jpn.13209

Zhang T, Du H, Feng S, Wu R, Chen T, Jiang J, Peng Y, Ye C, Fang R (2019) NLRP3/ASC/Caspase-1 axis and serine protease activity are involved in neutrophil IL-1 $\beta$ processing during Streptococcus pneumoniae infection. Biochem Bioph Res Co 513:675-680. https://doi.org/10.1016/j. bbrc.2019.04.004

Zhang L, Jiang X, Li A, Waqas M, Gao X, Li K, Xie G, Zhang J, Mehmood K, Zhao S, Wangdui B, Li J (2020) Characterization of the microbial community structure in intestinal segments of yak (Bos grunniens). Anaerobe 61:102115. https://doi.org/10.1016/j.anaerobe.2019.102115

Zhao XH, Chen ZD, Zhou S, Song XZ, Ouyang KX, Pan K, Xu LJ, Liu CJ, Qu MR (2017) Effects of daidzein on performance, serum metabolites, nutrient digestibility, and fecal bacterial community in bull calves. Anim Feed Sci Tech 225:87-96. https://doi.org/10.1016/j.anifeedsci.2017.01.014

\section{Publisher's Note}

Springer Nature remains neutral with regard to jurisdictional claims in published maps and institutional affiliations. 